\title{
Valley-Mountain Circulation Associated with the Diurnal Cycle of Precipitation in the Tropical Andes (Santa River Basin, Peru)
}

\author{
Alan G. Rosales ${ }^{1, *}$, Clementine Junquas ${ }^{2, *}$, Rosmeri P. da Rocha ${ }^{3}{ }^{\circledR}$, Thomas Condom ${ }^{2} \mathbb{D}$ and \\ Jhan-Carlo Espinoza ${ }^{2}$ \\ 1 Department of Earth and Atmospheric Science, Central Michigan University (CMU), \\ Mount Pleasant, SC 48859, USA \\ 2 University Grenoble Alpes, IRD, CNRS, Grenoble INP, IGE, 38000 Grenoble, France; \\ thomas.condom@ird.fr (T.C.); jhan-carlo.espinoza@ird.fr (J.-C.E.) \\ 3 Departamento de Ciências Atmosféricas, Universidade de São Paulo, São Paulo 05508, Brazil; \\ rosmerir.rocha@iag.usp.br \\ * Correspondence: jesusgarciabio@gmail.com (A.G.R.); clementine.junquas@univ-grenoble-alpes.fr (C.J.)
}

check for

updates

Citation: Rosales, A.G.; Junquas, C.; da Rocha, R.P.; Condom, T.; Espinoza, J.-C. Valley-Mountain Circulation Associated with the Diurnal Cycle of Precipitation in the Tropical Andes (Santa River Basin, Peru). Atmosphere 2022, 13, 344. https://doi.org/ $10.3390 /$ atmos13020344

Academic Editors: Bo Huang, Huidong Li and Jimy Dudhia

Received: 21 January 2022

Accepted: 15 February 2022

Published: 18 February 2022

Publisher's Note: MDPI stays neutral with regard to jurisdictional claims in published maps and institutional affiliations.

Copyright: (c) 2022 by the authors. Licensee MDPI, Basel, Switzerland. This article is an open access article distributed under the terms and conditions of the Creative Commons Attribution (CC BY) license (https:// creativecommons.org/licenses/by/ $4.0 /)$.
Abstract: The Cordillera Blanca (central Andes of Peru) represents the largest concentration of tropical glaciers in the world. The atmospheric processes related to precipitations are still scarcely studied in this region. The main objective of this study is to understand the atmospheric processes of interaction between local and regional scales controlling the diurnal cycle of precipitation over the Santa River basin located between the Cordillera Blanca and the Cordillera Negra. The rainy season (December-March) of 2012-2013 is chosen to perform simulations with the WRF (Weather Research and Forecasting) model, with two domains at $6 \mathrm{~km}$ (WRF-6 km) and $2 \mathrm{~km}$ (WRF-2 km) horizontal resolutions, forced by ERA5. WRF-2 $\mathrm{km}$ precipitation shows a clear improvement over WRF-6 km in terms of the daily mean and diurnal cycle, compared to in situ observations. WRF-2 km shows that the moisture from the Pacific Ocean is a key process modulating the diurnal cycle of precipitation over the Santa River basin in interaction with moisture fluxes from the Amazon basin. In particular, a channeling thermally orographic flow is described as controlling the afternoon precipitation along the Santa valley. In addition, in the highest parts of the Santa River basin (in both cordilleras) and the southern part, maximum precipitation occurs earlier than the lowest parts and the bottom of the valley in the central part of the basin, associated with the intensification of the channeling flow by upslope cross-valley winds during mid-afternoon and its decrease during late afternoon/early night.

Keywords: WRF model; precipitation; diurnal cycle; tropical Andes; Santa River basin

\section{Introduction}

Over the Andes Mountain, the Cordillera Blanca represents the major concentration of tropical glaciers in the world and constitutes approximately 35\% of the Peruvian Glaciers [1]. In the Santa River, glaciers allow for maintaining relatively stable flow during the dry season (May-September), favoring agriculture, the main economic activity in the region, and the production of electrical energy (e.g., the hydropower station of El Cañón del Pato; [2]. The retreat of glaciers in the last five decades represents a significant risk for the food and energy security of the region [3-6]. Ref. [5] has shown that the fluctuations of the mass balance of the tropical glaciers are significatively affected by the interannual precipitation variability. Therefore, the importance of studying the atmospheric mechanisms related to precipitation variability over the Cordillera Blanca region is evident.

The atmospheric numerical models and reanalysis are tools to evaluate and analyze the atmospheric processes related to precipitation. In the tropical Andes, both reanalysis and global circulation models (GCMs) do not yet have the spatial resolution to represent processes at the local scale. Therefore, using regional climate models (RCMs) as dynamical downscaling techniques, such as the Weather Research and Forecasting (WRF) model, 
is a way to study physical processes in the tropical Andes region [7-12]. Few studies exist using the WRF model in the Cordillera Blanca [13]. Different options of physical parameterizations are available using the WRF model, such as the convection, microphysics, radiation, soil surface, and planetary boundary layer [14]. Therefore, we can configure the model to simulate local processes associated with precipitation in the Andes. Besides, the WRF simulations allow increasing spatial and temporal resolutions to take into account the atmosphere tri-dimensional structure complexity in a region of complex topography [15].

In the work of [13], a relatively large amount of good-quality in-situ data was collected for the 2012-2013 wet season from December to March (DJFM). Their analysis pointed out a relatively good performance of WRF simulations in terms of diurnal cycle precipitation, which has not been fully studied yet, particularly in terms of atmospheric processes. Therefore, this paper aims to understand the key roles of the local and regional atmospheric mechanisms associated with developing the diurnal cycle precipitation in the Santa River basin during the wet season. Following [13], the 2012-2013 hydrological year is taken to represent neutral climate conditions in this region. This paper aims to understand the key roles of the local and regional atmospheric mechanisms associated with the development of the diurnal precipitation cycle in the Santa River basin during the wet season from December to March (DJFM). The paper is organized as follows. Section 2 is dedicated to describing the tropical Andes' main climatic features, particularly over the Santa River basin. Section 3 describes the precipitation datasets and model setup used in the research. Section 4 shows the validation process by comparing the in situ observed data and simulated diurnal cycle of precipitation. Section 5 explores atmospheric processes such as moisture flux, convergence, and circulation patterns associated with the diurnal precipitation cycle. Finally, Section 6 summarizes and concludes the main results.

\section{Main Climatic Features}

The Santa River basin, located in the central Peruvian Andes $\left(10.23^{\circ}-7.97^{\circ} \mathrm{S}\right.$ and $78.65^{\circ}-77.17^{\circ} \mathrm{W}$; Figure 1), has an extension of $11,910 \mathrm{~km}^{2}$ and is part of the Pacific hydrographic basin surrounded on its western side by the Cordillera Negra (a mountainous chain lacking glaciers with altitudes between 4800 m.a.s.l. and 5187 m.a.s.l.) and on the eastern side by the Cordillera Blanca (the largest glacial chain of Peru and the location of the highest glacier in Peru, Huascarán, at 6767 m.a.s.1.), comprising the Occidental Cordillera (Figure 1a,b). The Andes Mountain range is the essential topographic feature in South America, extending from Colombia to the continent's southern tip $\left(10^{\circ} \mathrm{N}-53^{\circ} \mathrm{S}\right)$, with a maximum altitude of $6962 \mathrm{~m}$ above sea level and a width of less than $200 \mathrm{~km}$ at tropical latitudes. While this mountain has not been fully studied in the tropics and subtropics [16], the presence of the Andes has a strong impact on the large-scale precipitation variability and the associated atmospheric circulation (e.g., $[13,15,17,18])$. On the east side of the tropical Andes, high humidity values predominate at low and medium levels of the troposphere (e.g., [15,17-20]), as the Amazonian plains are a large source of moisture (e.g., [21-24]). On the other hand, on the west side of the tropical Andes, the South Pacific subtropical Anticyclone (SPA) and the descending branch of the Walker circulation establish strong subsidence with dry and stable conditions. During the austral summer (December-March), the surface wind has a strong northward component associated with the presence of the SPA along most of the west coast of South America [25]. Besides, an extended coastal sea-breeze mechanism is created due to diurnal solar heating of the coastal land surfaces [26,27], influencing the precipitation variability at the local scale [28]. These surface winds are locally dependent on the orography configuration, and therefore they do not reach the eastern side of the Andes (e.g., [25]). However, their characteristics and influence on regional circulation and precipitation variability have been scarcely studied. 


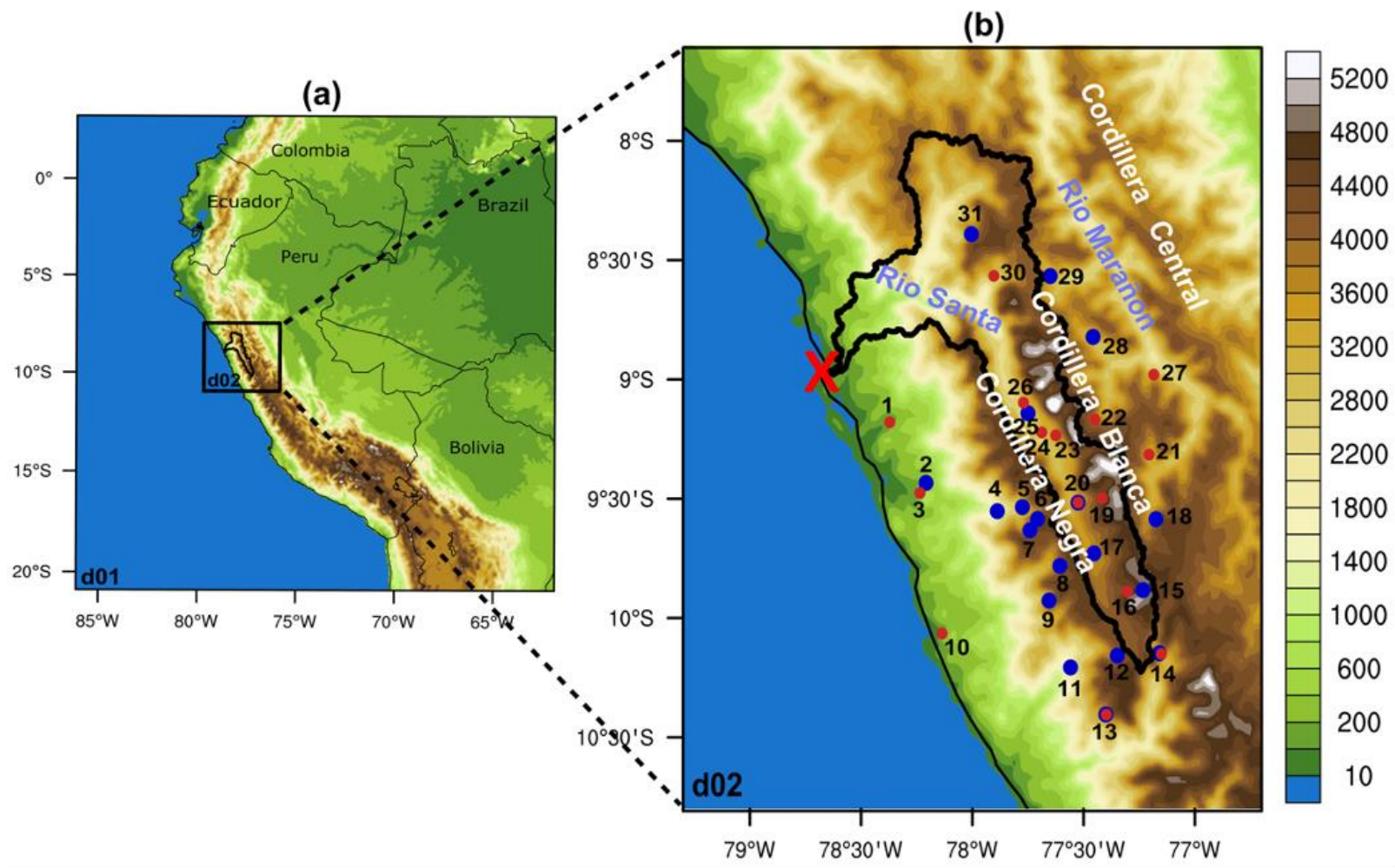

Figure 1. (a) Location of the Santa River basin in central Peruvian Andes and WRF domains for WRF-6km (d01) and WRF-2 km (d02) with corresponding WRF topography (shaded; m.a.s.l.). (b) Geographical details of d02. In both panels, the upper Santa River basin location is indicated in the bold black line. In (b), color dots indicate the meteorological station positions with their respective reference number (Table S1). Blue and orange dots correspond to SENAMHI and UNASAM stations, respectively. The red cross indicates the outlet of the basin.

At the upper level $(200 \mathrm{hPa})$, circulation during the austral summer in tropical South America is dominated by the presence of the large anticyclonic circulation called the Bolivian High, which was first identified by [29,30]. It is centered near $15^{\circ} \mathrm{S}$ and $65^{\circ} \mathrm{W}$ [31], and numerical experiments indicate that the formation of the Bolivian High structure is an atmospheric circulation response of diabatic warming of the rainfall over the Amazon basin $[32,33]$. Some studies suggest that its intensification and southward movement are associated with intense precipitation over the Altiplano [32,34], particularly before the 2000s (Segura et al., 2020). The South Atlantic Convergence Zone (SACZ) is a distinctive feature [35] and an indicator of the mature phase of the South American Monsoon System (SAMS; [31,36]. Moreover, this phase is associated with deep convection over the Amazon basin. During this period, a huge amount of moisture is transported from the tropical Atlantic Ocean, where the Intertropical Convergence Zone (ITCZ) organizes deep convection between $5^{\circ}$ to $8^{\circ} \mathrm{N}$ [37] to the Amazon basin by the trade winds [31]. This moisture transport and water recycling through evapotranspiration over the Amazonian rainforest increases the moisture in the planetary boundary layer and the temperature at the top of the layer, favoring convection in tropical South America [38,39], including western Amazon/eastern Andes [40]. The northeasterly winds turn northwesterly when encountering the Andes, through an anticyclonic low-level gyre produced by the atmospheric response of the diabatic latent heating released by the SAMS [33,41,42]. Therefore, moisture is transported southward by the South American Low-Level Jet (SALLJ) on the eastern side of the Andes [39]. The interaction of the north/northwest meridional flow in the eastern flanks of the Central Andes is associated with the formation of deep precipitation nuclei called "rainfall hotspots" [20]. In the Altiplano region, in the central part of the Andes $\left(15^{\circ}-22^{\circ} \mathrm{S}\right)$, the austral summer season is well-known for the destabilization of the local troposphere 
by intense surface heating and the presence of stronger-than-normal upper-level easterly winds that favor the transport of moist air from the interior of the continent. In addition, the rainy episodes are associated with intensification and southward displacement of the Bolivian High $[15,17,32]$. A second mechanism related to rainy episodes over central tropical Andes is the upward atmospheric motion over the western Amazon, part of the meridional circulation between the tropical North Atlantic and western tropical South America [40].

As mentioned, several studies discuss the influence of the Andes on large-scale circulation over South America. Conversely, the interactions between local (valley-mountain circulation) and regional processes associated with the diurnal precipitation cycle have not yet been adequately explored over the tropical Andes and especially over its western side. According to previous studies, the Andean orography, including valleys and intra-Andean valleys, establishes the local context that characterizes the atmospheric circulation associated with precipitation (e.g., $[43,44])$. In the eastern side of the tropical Andes, some local atmospheric mechanisms have been identified as being associated with the diurnal cycle precipitation, including thermally driven winds, orographic blocking, channelization of the moisture transport, nighttime mesoscale convective systems, etc. (e.g., [7,45-50]). However, the local circulations have been scarcely analyzed over the Pacific side of the tropical Andes. Recently, [28] identified an orographic precipitation gradient along western Andean valleys (Ecuador) perpendicular to the coast using observations and atmospheric simulations. They identified an anabatic upward flow during the day, favoring the convection development on top of the mountains during the afternoon. In this way, the western Andean orography influences the local circulation and precipitation development. Therefore, it is crucial to develop studies focused on this topic and understand the regional and local interactions of the physical atmospheric mechanisms controlling precipitation on the western side of the tropical Andes.

\section{Data and Model}

\subsection{In Situ Data}

We use precipitation data of 15 meteorological stations from the Universidad Nacional Santiago Antúñez de Mayolo (UNASAM) of Huaraz and 19 from the Peruvian National Meteorology and Hydrology Service (SENAMHI) (Table S1). The daily rainfall amounts at the SENAMHI stations are obtained from measures twice a day at 07 and 19 local times (LT), and the 07 LT measurement is considered the previous day. The UNASAM stations provide hourly rainfall data (Table S1). These datasets were used by [13], which employed rigorous quality control for SENAMHI data and compared precipitation amounts reported by stations located in the same area, removing incorrect values for UNASAM data. We used these data to validate the WRF simulations and compare them with other gridded precipitation products.

\subsection{Precipitation Products}

The daily rainfall analysis from Climate Hazards Group InfraRed Precipitation with Station data (CHIRPS; [51]) version 2.0 is used. It encompasses the continental parts of the globe between $50^{\circ} \mathrm{N}$ to $50^{\circ} \mathrm{S}$ and has been available from 1981 to the present. CHIRPS incorporates $0.05^{\circ}$-resolution satellite imagery with in situ station data to generate gridded daily rainfall analysis. This dataset is accessible at the website https: / / data.chc.ucsb.edu/ products/CHIRPS-2.0; 12 November 2022. Another set of gridded observed data is the Peruvian Interpolated data of the SENAMHI's Climatological and hydrological Observations (PISCO; https://iridl.ldeo.columbia.edu/SOURCES/.SENAMHI/.HSR/.PISCO/; 12 November 2022) version 2.0 using the Climate Hazards Precipitation Climatology (CHPClim) and the Tropical Rainfall Measuring Mission (TRMM; https:/ / disc.gsfc.nasa.gov; 12 November 2022) 2A25 dataset. PISCO data's fine horizontal grid spacing $(\sim 5 \mathrm{~km})$ is helpful to validate WRF in Andes regions, as demonstrated by [9].

The TRMM 3B42 version 7 precipitation product, hereafter TRMM3B42 ([52,53]), incorporates high-grade infrared (IR) precipitation estimations and root-mean-square 
(RMS) precipitation-error estimates. The data covers $50^{\circ} \mathrm{N}$ to $50^{\circ} \mathrm{S}$ and all longitudes, with a spatial resolution of $0.25^{\circ}$ (approximately $27 \mathrm{~km}$ ) available every $3 \mathrm{~h}$. TRMM3B42 has been used in many studies to analyze the spatial pattern of Andes precipitation (e.g., $[6,7,9,10,13])$. Furthermore, the National Oceanic and Atmospheric Administration (NOAA) CPC Morphing Technique [54] generates global precipitation analyses at very fine horizontal grid spacing $(8 \mathrm{~km})$ and temporal $(30 \mathrm{~min})$ resolutions. CMORPH incorporates precipitation estimates derived from low-orbit satellite microwave observations exclusively, acquired only from geostationary satellite IR data, which is available on the website https: / / www.ncei.noaa.gov / products / climate-data-records / precipitation-cmorph; 12 November 2022.

\subsection{WRF Simulations}

The regional atmospheric simulations in the Santa River basin are performed with the Weather Research and Forecasting (WRF) model, version 3.8.1, using terrain-following vertical coordinates [14]. The simulation is executed as a one-way nesting with two domains. The first domain has $6 \mathrm{~km}$ of horizontal resolution (WRF-6 km), with lateral boundary conditions from 6-hourly ERA5 reanalysis and without nudging to allow the model abilities to develop local circulations. The second domain has a grid spacing of $2 \mathrm{~km}$ (WRF-2 km) (Figure 1). The study period is from December 2012 to March 2013 (DJFM, austral summer season), and the simulation started on the 21st of November of 2012, with the first ten days considered the spin-up time and not used in the analysis. Table 1 resumes the principal features of the simulations. This period was chosen because of the availability of in situ station data and also corresponds to a year with annual precipitation values close to the mean precipitation of the 1965-2014 period as calculated from 10 long-term stations among the ones used in this study and in [13].

Table 1. Characteristics of the WRF simulations at the three different spatial grids.

\begin{tabular}{ccc}
\hline & D01 $\mathbf{( W R F - 6 ~ k m )}$ & D02 $\mathbf{( W R F - 2 ~} \mathbf{~ k m})$ \\
\hline Domain & Tropical Andes & Rio Santa region \\
Configuration & Regional simulation & One-way nesting \\
Horizontal grid spacing $(\mathrm{km})$ & 6 & 2 \\
Number of grid points & $391 \times 397$ & $187 \times 172$ \\
Vertical resolution & 38 sigma levels & 38 sigma levels \\
Forcing & ERA5 & WRF6 \\
Run time step (s) & 12 & 4 \\
Output time resolution (h) & 1 & 1 \\
Period & December 2012-March 2013 & December 2012-March 2013 \\
\hline
\end{tabular}

We tested different parametrization schemes using the WRF-6 km domain to identify the most appropriate setup to describe the observed diurnal cycle of precipitation during March 2013 [55]. We chose the WRF-6 km configuration that presents lesser errors (in terms of bias, root mean square error, mean absolute error, and diurnal cycle phase and amplitude) to reproduce precipitation characteristics compared to in situ observations to provide boundary conditions to WRF-2 km simulation. The performance of the final configuration of the simulations in terms of statistical metrics and the diurnal cycle of precipitation is described in more detail in Section 4.1. The physical parameterizations used in the final configuration are listed in Table 2. We use the Betts-Miller-Janjic ensemble scheme for the cumulus parameterization, activated WRF-6 km, and deactivated WRF-2 $\mathrm{km}$ [56-58]. This parameterization is a step-like mountain model with eta coordinates that includes modifications of the triggering mechanism to improve its performance for higher horizontal resolutions. Other parameterizations activated in both domains are (a) the Goddard microphysical scheme [59], (b) surface layer parameterization from the Mellor-Yamada-Nakanishi-Niino scheme [60], and the (c) surface model from Noah multiphysics with a snow option $[61,62]$ as previously tested in the Cordillera Blanca in Peru [13]. 
The forcing topography data used by default in this version of WRF (version 3.8.1) were previously identified with good representativeness (version 3.8 and beyond; [12,63]).

Table 2. Physical parameterizations used in the sensitivity WRF simulation tests.

\begin{tabular}{ccc}
\hline & Parameterization & References \\
\hline Planetary boundary layer & $\begin{array}{c}\text { Mellor-Yamada Nakanishi } \\
\text { and Niino Level 2.5 } \\
\text { (MYNN2) }\end{array}$ & {$[60]$} \\
\hline Surface layer & MYNN & {$[60,64]$} \\
\hline Land Surface & $\begin{array}{c}\text { Noah-MP (multi-physics) } \\
\text { with precipitation partitioning } \\
\text { between snow and rain } \\
\text { (option 2) }\end{array}$ & {$[61,62]$} \\
\hline Cumulus parameterization & Betts-Miller-Janjic & {$[56-58]$} \\
\hline Microphysics & Goddard & {$[59]$} \\
\hline Radiation & $\begin{array}{c}\text { Longwave:Rapid Radiative } \\
\text { Transfer Model (RRTM) }\end{array}$ & {$[65]$} \\
\cline { 2 - 3 } & Shortwave: Dudhia scheme & {$[66]$} \\
\hline
\end{tabular}

\section{Evaluation of the Diurnal Cycle of Precipitation in the Santa River Basin}

\subsection{Local Scale}

The precipitation diurnal cycle is a key feature to evaluate the quality of the parameterizations of moist processes used by models [67]. Figure 2 shows that at the stations located in the north and the center of the Santa valley (Cañasbamba, Corongo, Quillcayhuanca, Shancayan, Shilla, and Tingua), the amount of precipitation is more intense, from 16 to 21 LT with main peaks from 17 to 19 LT. The simulations can reproduce these main features. WRF-2 km shows better results than WRF- $6 \mathrm{~km}$ in most stations, particularly at Cañasbamba, where it reduces the 19-20 LT overestimated WRF-6 km peak, and at Corongo, where it removes an unrealistic 12-13 LT WRF-6 km peak. The precipitation starts earlier (near 14 LT) in the stations located in the part south of the basin (for example, in Ocros, Pasto Ruri, and Chiquián). WRF-6 km and WRF-2 km have a similar diurnal time evolution of rainfall at Pasto Ruri when compared to observations. WRF- $6 \mathrm{~km}$ shows an early three-hour lag at Chiquián, which is largely decreased in WRF-2 km. A similar early initiation of rainfall is found in Ocros, situated south of the Santa River basin, on the western slope (Pacific coast), and at Purhuay on the eastern slope (Marañón valley). WRF-2 $\mathrm{km}$ improves the WRF-6 km lag at Purhuay but amplifies it at Ocros.

To summarize, the increase in spatial resolution from $6 \mathrm{~km}$ to $2 \mathrm{~km}$ improves the representation of the diurnal precipitation cycle compared to observed data. This confirms previous studies showing better performance of the WRF model at the highest resolutions in the tropical Andes (e.g., $[9,13])$. In this context, the more realistic representation of the diurnal cycle of rainfall by WRF-2 km provides confidence to investigate the associated atmospheric local and regional circulations controlling the Santa River basin precipitation.

The DJFM mean precipitation means from TRMM3B42, CMORPH, CHIRPS, PISCO, and WRF-6 km and WRF-2 km are displayed in Figure 3. Every product except PISCO shows intense precipitation over the Cordillera Blanca. Considering only the Santa River basin, TRMM3B42 and CMORPH (Figure 3a,b) display a strong precipitation core on the highest peaks of the Cordillera Blanca $\left(\sim 9^{\circ} 15^{\prime} \mathrm{S}-77^{\circ} 45^{\prime} \mathrm{W}\right)$, which differs from CHIRPS and PISCO where the precipitation has a more uniform spatial distribution (Figure 3c,d). While CHIRPS shows slightly stronger precipitation in the Cordillera Blanca than in the Santa valley below $3500 \mathrm{~m}$ (Figure 3d), PISCO presents similar amounts in these two regions (Figure 3c). As PISCO is a product based on both satellite and station data, it is worth noting that meteorological stations are scarce or nonexistent in the highest parts of Cordillera 
(Figure 1b; Table S1). Therefore, while PISCO seems to be an appropriate product for valley conditions, it is not necessarily the more appropriate one to represent the Spatio-temporal variability of precipitation in terms of orographic gradients. WRF- $6 \mathrm{~km}$ and WRF-2 km simulate the observed pattern of spatial precipitation variability shown by the gridded products (more rainfall over the Cordillera Blanca than in the bottom of the Santa valley), except when compared to the PISCO (Figure 3e,f). A strong overestimation of precipitation by simulations is displayed in the entire region compared with most products, being greater in the Amazon basin (north-eastern part of Figure 3). However, the simulations can reproduce the dry conditions of the Pacific coast and in the western slope of the Cordillera Negra with less than $1.5 \mathrm{~mm}_{\text {day }}{ }^{-1}$ below $3500 \mathrm{~m}$.
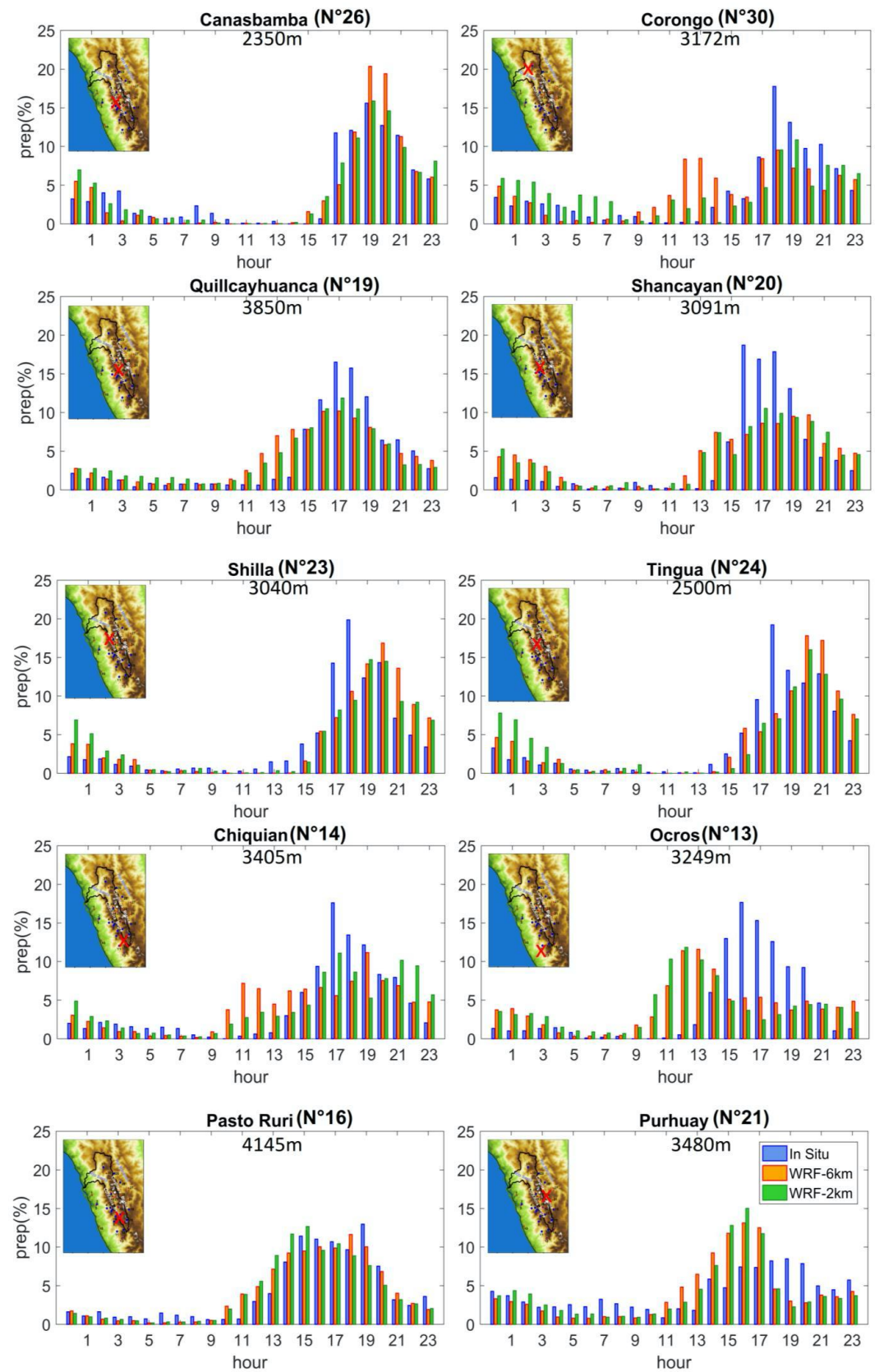

Figure 2. Histogram of the mean diurnal cycle of precipitation in percent (\%) of the total daily mean of the summer season (December 2012-March 2013; DJFM) along the Santa River basin, for ten automatic, in situ stations (blue bars), and the corresponding grid-point from WRF-6 km hourly (orange bars) and WRF-2 km hourly (green bars). The location of the stations and other geographical details are indicated in each inset panel. 
(a) TRMM3B42

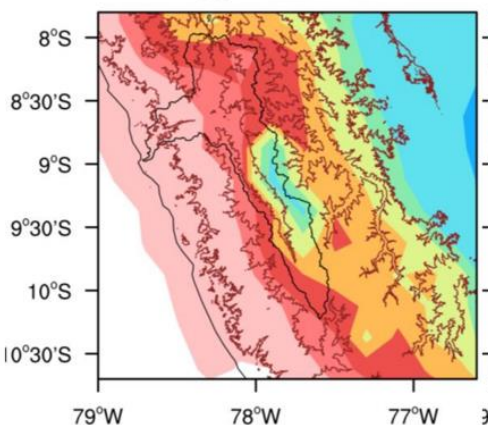

(d) CHIRPS

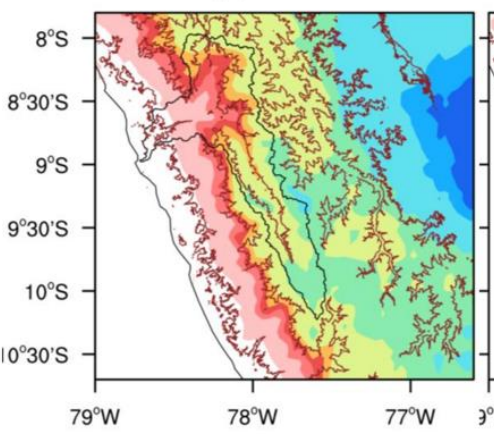

(b) CMORPH

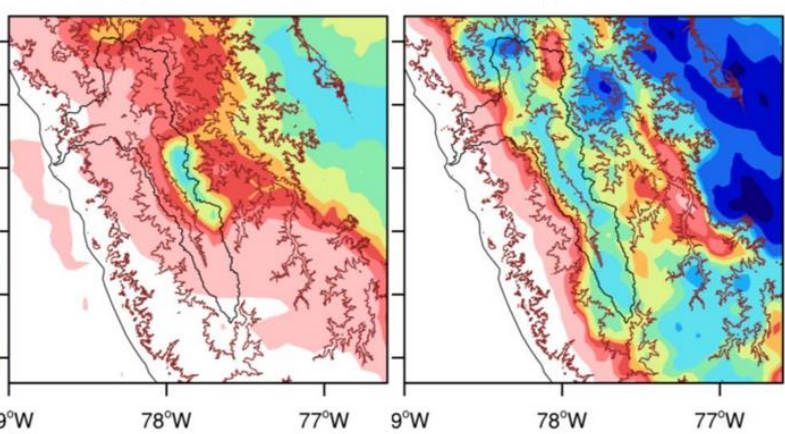

(e) WRF-6km

(f) WRF-2km

(c) PISCO

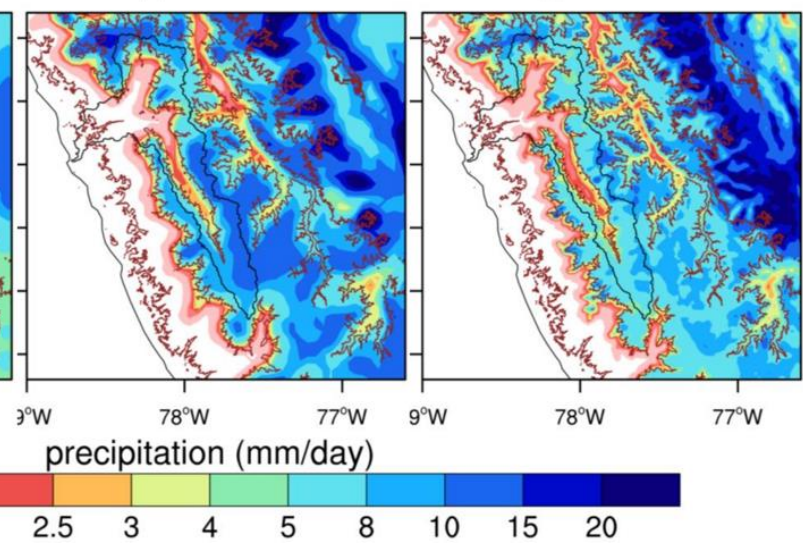

Figure 3. Mean precipitation $\left(\mathrm{mm} \mathrm{day}^{-1}\right.$ ) for the DJFM rainy season from (a) TRMM3B42, (b) CMORPH, (c) PISCO, (d) CHIRPS data, (e) WRF-6 km, and (f) WRF-2 km. The orography heights of 500 and $3500 \mathrm{~m}$ are highlighted in brown lines.

The Taylor diagram in Figure 4 presents the statistical indices between the DJFM mean precipitation of each product and the 27 stations shown in Figure 1. The spatial correlation (Figure 4) corroborates the previous analyses, presenting WRF-2 km with the highest correlation of 0.78 , a Standard Deviation (SD) of $2.27 \mathrm{~mm}$ day $^{-1}$ closer to the rain-gauge, and a smaller root mean square error (RMSE) of $1.47 \mathrm{~mm} \mathrm{day}^{-1}$. These indices confirm that WRF-2 km improves the WRF-6 km simulation and that, in addition, WRF-2 km shows greater agreement with the in situ data than other gridded products. Evaluating the gridded product, CHIRPS stands out by showing greater agreement with data from rain gauges since it presents small RMSE $\left(1.44 \mathrm{~mm}^{\text {day }}{ }^{-1}\right)$, high correlation $(\sim 0.76)$, and SD $\left(1.33 \mathrm{~mm}\right.$ day $\left.^{-1}\right)$ slightly lower than rain gauges. CMORPH has less ability to reproduce local observations, showing the largest RMSE $\left(2.02 \mathrm{~mm} \mathrm{day}^{-1}\right)$ and smallest spatial correlation $(\sim 0.45)$ and SD $\left(0.84 \mathrm{~mm} \mathrm{day}^{-1}\right)$.

These results confirm that caution should be taken with satellite results, confirming previous studies and that the PISCO interpolated dataset shows lower performance than CHIRPS in this region. In particular, previous studies have shown that the satellite datasets tend to underestimate precipitation over the tropical Andes (e.g., $[19,20,68,69])$. 


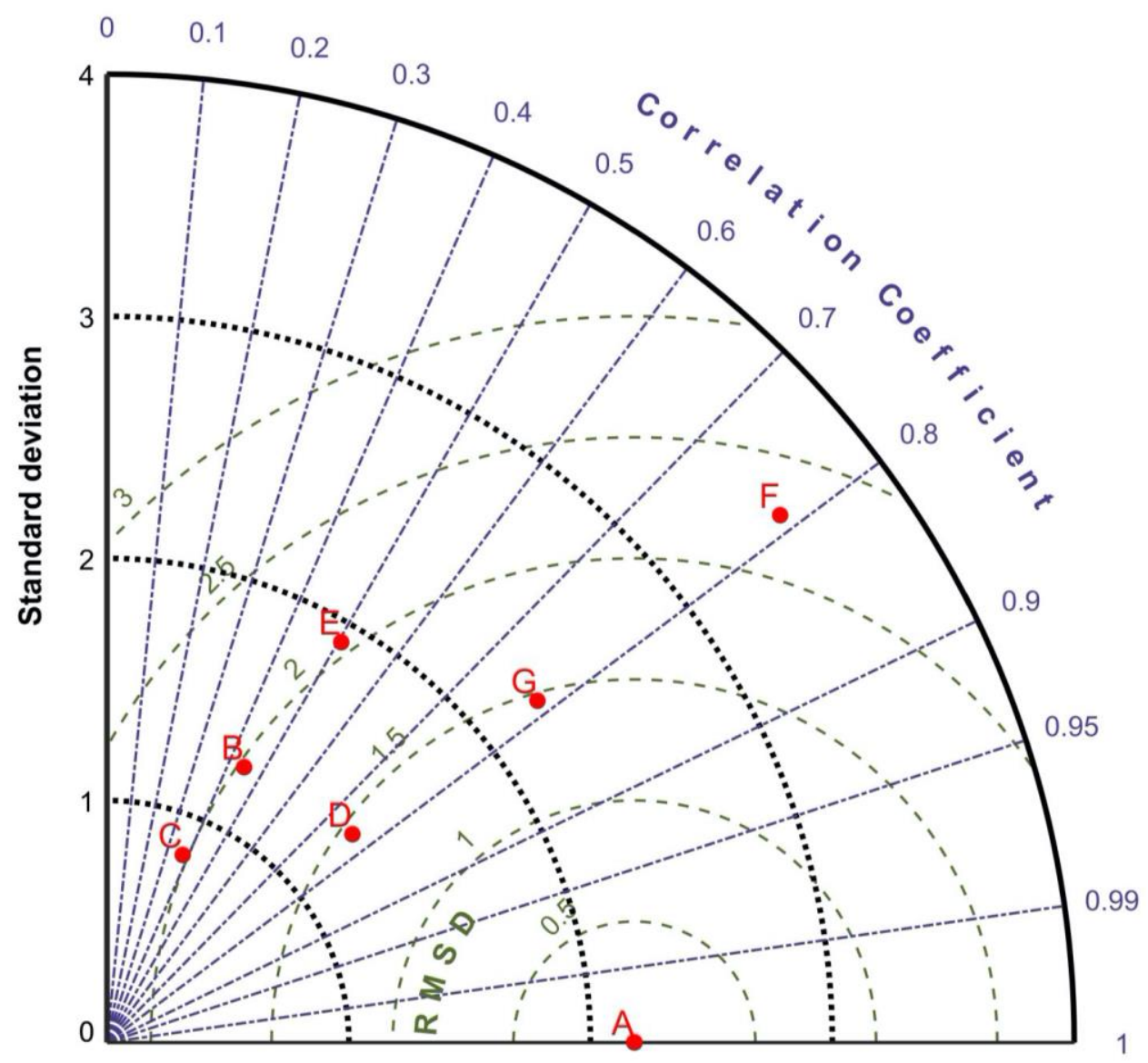

Figure 4. Taylor diagram for the mean precipitation $\left(\mathrm{mm} \mathrm{day}^{-1}\right)$ for DJFM, where the statistics are obtained by comparing TRMM3B42 (B), CMORPH (C), CHIRPS (D), PISCO (E), WRF-6 km (F), and WRF-2 km (G) with the in situ precipitation data (A).

\subsection{Regional Scale}

The regional atmospheric circulation from WRF- $6 \mathrm{~km}$ shows good agreement with ERA5 at lower $(850 \mathrm{hPa})$, upper $(200 \mathrm{hPa})$, and mid $(500 \mathrm{hPa})$ levels (Figure 5$)$. At the upper level ( $200 \mathrm{hPa}$; Figure $5 \mathrm{a}, \mathrm{d})$, both ERA 5 and WRF- $6 \mathrm{~km}$ present strong easterly winds crossing from the Amazon to northern Peru towards the Pacific Ocean. The anticyclonic circulation (with the center at a latitude of $\sim 15^{\circ} \mathrm{S}$ ) characterizes the presence of the western part of the Bolivian High. The northeasterly wind turns northwesterly, intensifying over the Pacific Ocean, northern Chile, and southern Bolivia. Therefore, for both ERA5 and WRF-6 $\mathrm{km}$, the center of the Bolivian High is in a location similar to the climatological center described by [31]. At middle levels ( $500 \mathrm{hPa}$; Figure 5b,e), ERA5 presents easterly winds that dominate circulation throughout Peru. WRF- $6 \mathrm{~km}$ simulates this feature but with more intense winds over the Pacific Ocean than ERA5. At a low level ( $850 \mathrm{hPa}$; Figure 5c,f), ERA5 shows intense northeasterly tropical winds in the north of Brazil that weaken as it reaches northern Peru. Likewise, WRF-6 km simulates these wind patterns with less intensity. Compared to ERA5, WRF-6 km underestimates wind intensity near the equator and overestimates it in the eastern slope of the Andes south of Peru and Bolivia. At the latitudes of the Santa River basin, the low-level wind intensity east of the Andes in WRF is similar to ERA5, which is relevant because it is part of the SALLJ at a seasonal scale. In the Pacific Ocean, WRF-6 km can show more intense winds in the north and south of the domain. However, in ERA5, a local coastal circulation perpendicular to the coast south of the Santa River basin latitudes is not reproduced by WRF-6 km. 
(a) $200 \mathrm{hPa}$

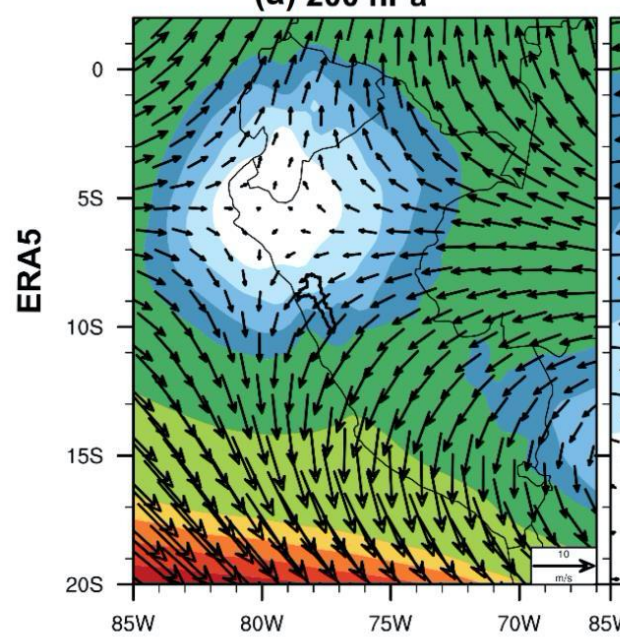

(b) $500 \mathrm{hPa}$

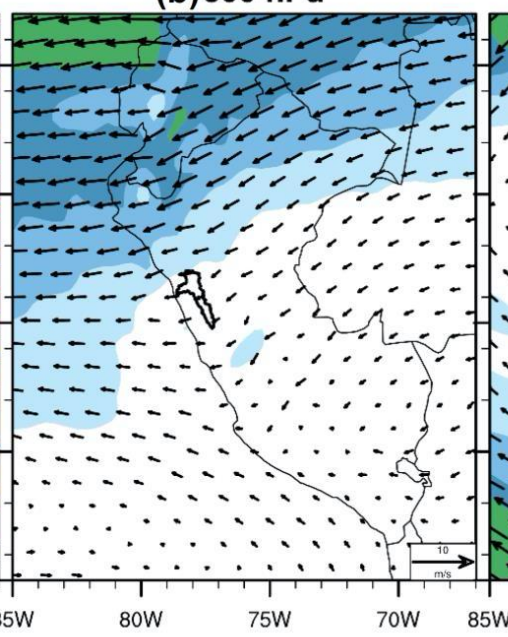

(c) $850 \mathrm{hPa}$

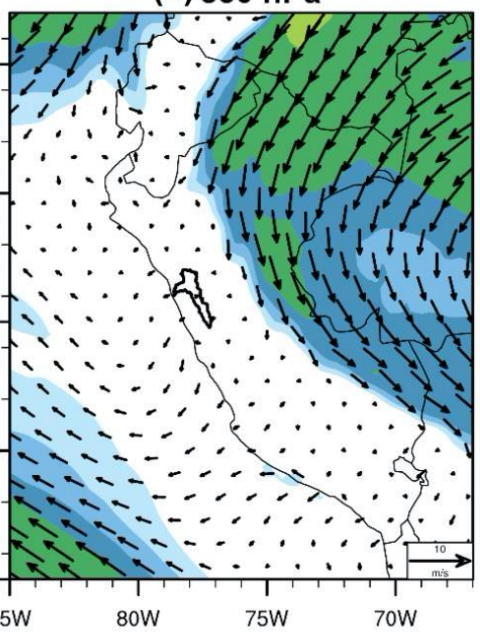

(f) $850 \mathrm{hPa}$

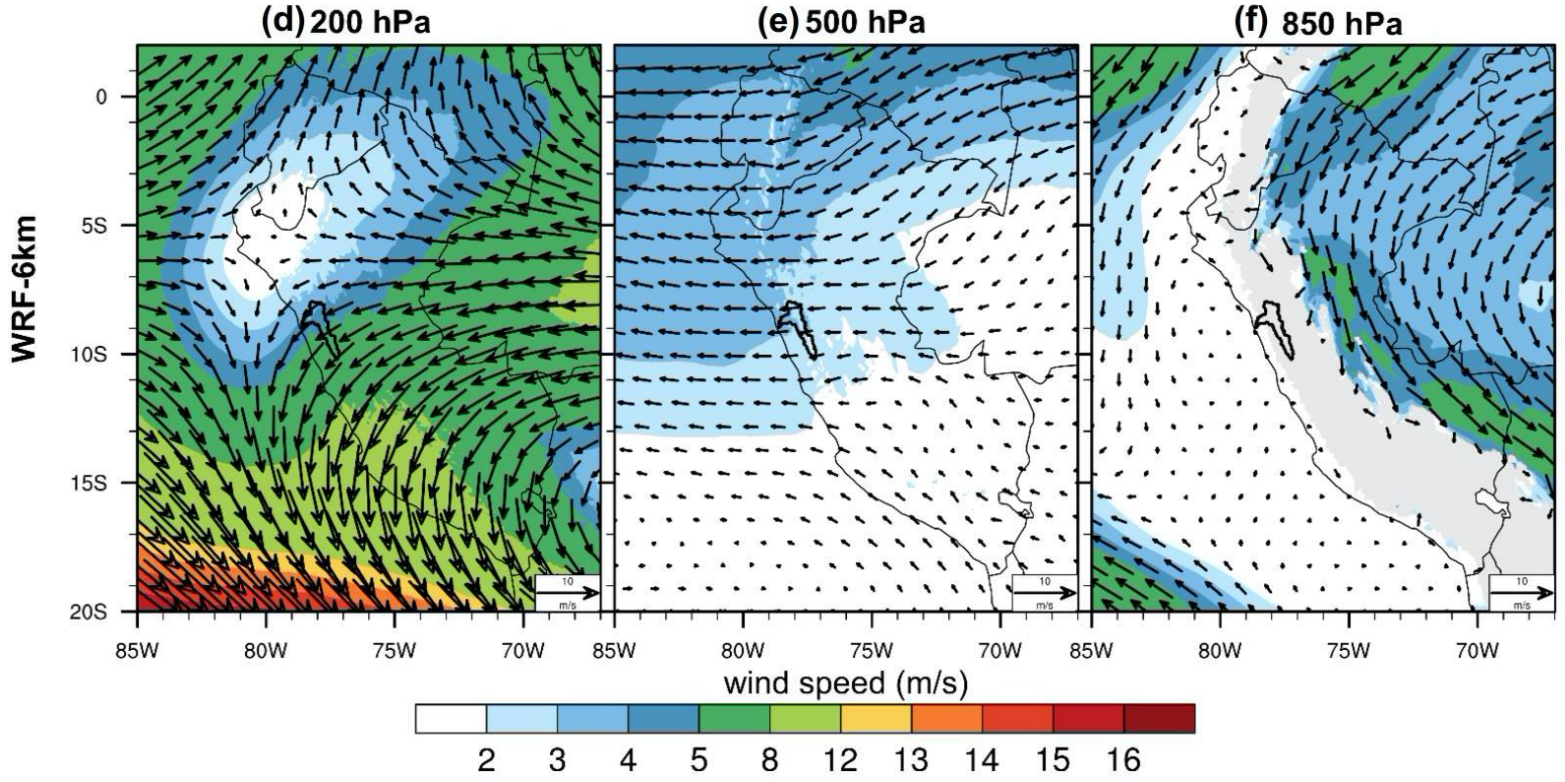

Figure 5. DJFM-averaged horizontal wind (arrows with intensity in shaded, $\mathrm{m} \mathrm{s}^{-1}$ ) at (a,d) $200 \mathrm{hPa}$, $(\mathbf{b}, \mathbf{e}) 500 \mathrm{hPa}$, and $(\mathbf{c}, \mathbf{f}) 850 \mathrm{hPa}$ obtained from $(\mathbf{a}-\mathbf{c})$ ERA 5 and $(\mathbf{d}-\mathbf{f})$ WRF-6 km. Santa River basin is indicated by bold black contour, while in (f) the grey zone delimitates the WRF orography at $850 \mathrm{hPa}$.

\section{Atmospheric Processes Associated with the Diurnal Cycle of Precipitation}

In this section, for the DJFM mean, the atmospheric processes are analyzed by the association between the spatial variability of the diurnal cycle of precipitation, circulation, moisture flux, and its convergence, based on WRF-2 km.

\subsection{Diurnal Cycle of Moisture Fluxes Related to Precipitation}

The simulated spatial precipitation patterns are different during the day and night (Figure $6 b, c)$. Over the western slope of the Cordillera Negra, the precipitation is high during the day (Figure 6b), while in the eastern side of the Cordillera Blanca, a greater amount of precipitation is simulated during the night (Figure $6 \mathrm{c}$ ). The maximum precipitation in the eastern slope of the Cordillera Central is also found during the night, associated with an Amazon hotspot of precipitation in the eastern Andes, as already mentioned by previous works (e.g., [7,19]). In the Santa River basin, precipitation presents a significant day-night contrast. The northern and southern zones of the basin are characterized by more intense precipitation during the day (altitudes above $3500 \mathrm{~m}$ ). In comparison, in the valley (below $3500 \mathrm{~m}$ ), maximum precipitation occurs during the night, demonstrating a 
strong altitude effect on the diurnal cycle of precipitation in the Santa River basin. Figure 7 shows the associated atmospheric circulation patterns in terms of vertically integrated moisture flux (from the surface to $200 \mathrm{hPa}$ ). The total daily mean (Figure 7a) presents an easterly flow with the main moisture flux convergence patterns associated with the main precipitation patterns (Figure 6a). The daytime and nighttime anomalies (Figure $7 \mathrm{~b}, \mathrm{c}$, respectively) highlight the local processes, i.e., an along-valley upward (downward) flux anomaly during the day (during the night) in the Santa valley. During the night, the moisture flux convergence anomalies are particularly strong over the western slope of the Cordillera Blanca and below $3500 \mathrm{~m}$ in the northwestern part of the basin (Figure 7c). Therefore, the local scale seems to dominate over the regional scale in terms of diurnal anomalies of the atmospheric circulation in the Santa River basin. The local along-valley circulation along the Santa valley, in particular, seems to play a role in the triggering of the convection.

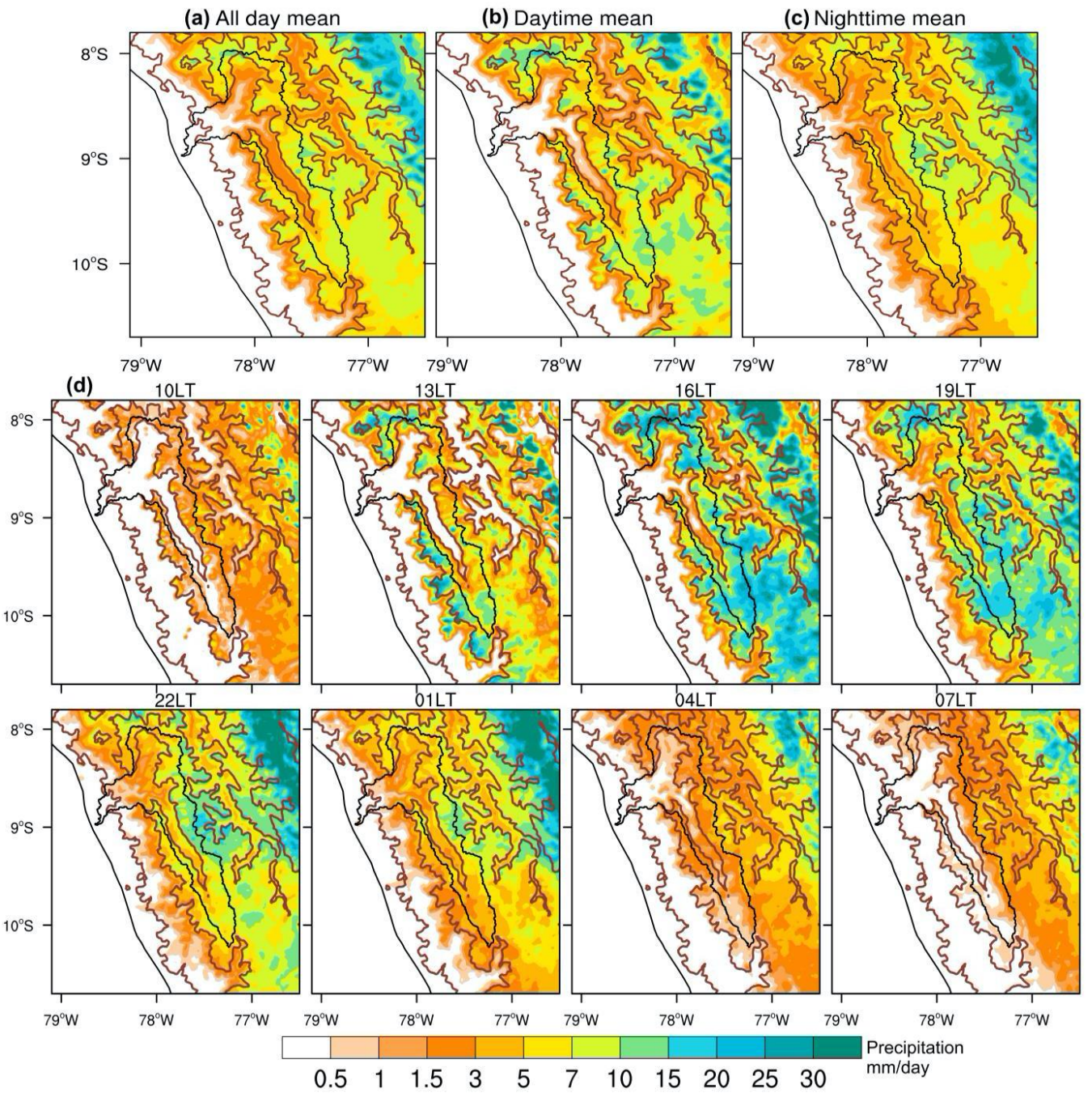

Figure 6. Mean precipitation ( $\mathrm{mm} \mathrm{day}^{-1}$ ) for DJFM simulated by WRF-2 $\mathrm{km}$ corresponding to (a) all-day mean (0-23 LT), (b) daytime mean (7-18 LT), (c) nighttime mean (19-6 LT), and (d) 3-hourly time-step as indicated in each panel. The orography limits of 500 and $3500 \mathrm{~m}$ are highlighted in bold line, while black lines delimitate Santa River basin and coastline. 
(a) All day mean

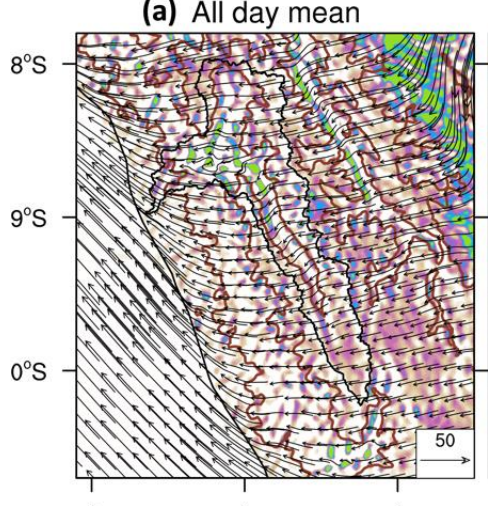

(b) Daytime anomalies

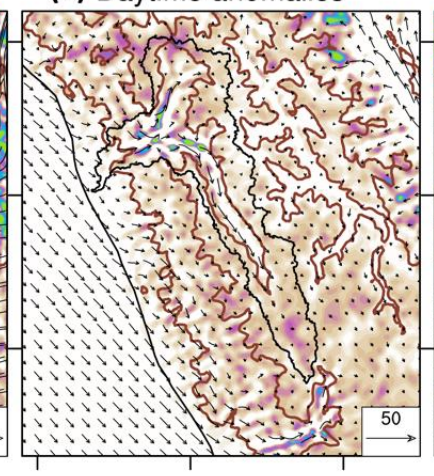

$79^{\circ} \mathrm{W}$ (c) Nighttime anomalies

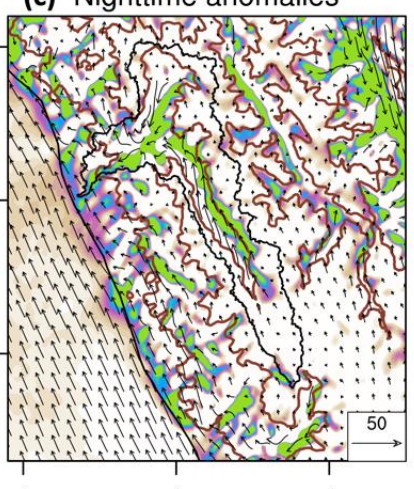

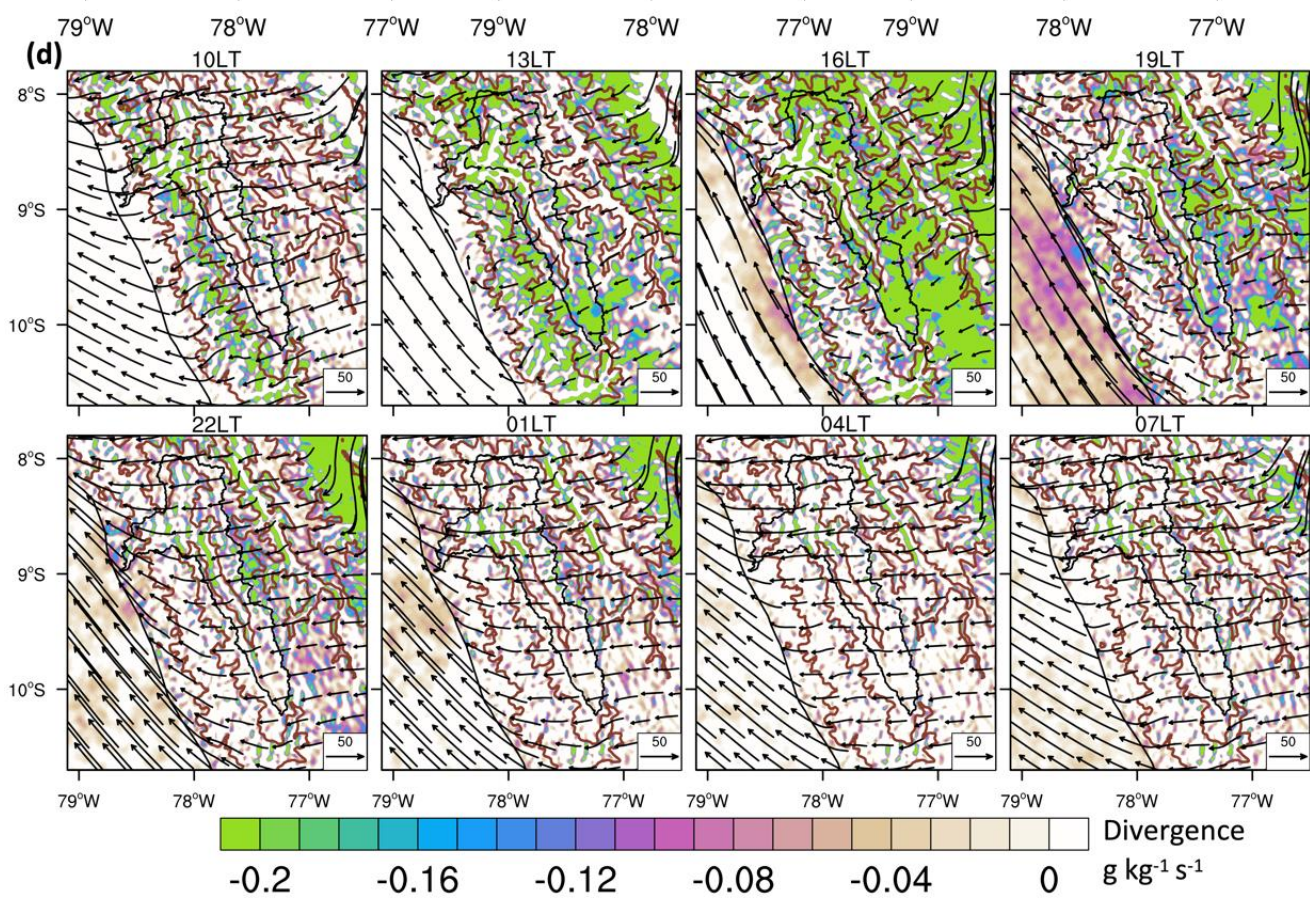

Figure 7. Vertically integrated (from the surface to $200 \mathrm{hPa}$ ) moisture flux (arrows) and its divergence (color) for DJFM as simulated by WRF-2 km for (a) all-day mean (0-23 LT), (b) daytime mean (7-18 LT) minus daily mean, (c) nighttime mean (19-6 LT) minus daily mean, and (d) 3-hourly time-step as indicated in each panel. Reference vector in $\mathrm{g} \mathrm{kg}^{-1} \mathrm{~m} \mathrm{~s}^{-1}$ is displayed at the lower right corner of each panel. Units of divergence: $10^{3} \mathrm{~g} \mathrm{~kg}^{-1} \mathrm{~s}^{-1}$. The orography limits of 500 and $3500 \mathrm{~m}$ are highlighted in bold brown lines, while black lines delimitate the Santa River basin and coastline.

The diurnal cycle of precipitation in Figure 6d presents an early afternoon (13 LT) maximum of rainfall over the Cordillera Negra (western side of the basin in the altitudes above $3500 \mathrm{~m}$ ). In contrast, the precipitation over the Cordillera Blanca (eastern side of the basin) starts at $13 \mathrm{LT}$ reaching the maximum at $19 \mathrm{LT}$, which occurs at the same time that precipitation is decreasing over the Cordillera Negra. Therefore, it is important not to simply summarize the precipitation diurnal cycle with day and night periods. In the Santa valley below $3500 \mathrm{~m}$, precipitation occurs in the late afternoon and early night (19-01 LT), and similar behavior is found in the Marañón valley East of the Cordillera Blanca. Moreover, this precipitation behavior is consistent with the in situ station data, showing the maximum between $18 \mathrm{LT}$ and $21 \mathrm{LT}$ at altitudes below $3500 \mathrm{~m}$ (Figure 2; Cañasbamba, Tingua). In Figure $7 \mathrm{~d}$, it is noted during the early night (19-01 LT) that the presence of SALLJ intensifies the southwestward moist flow over the Amazon slope of the Andes. As a consequence, a flow more parallel to the Andes moisture flux is established, which decreases the Amazon moisture supplies to the basin. Another relevant aspect is the coastal flow convergence near the latitude of $8^{\circ} 45^{\prime}$ S, i.e., at the outlet of Santa Rita basin. This flow turns into a 
parallel orientation to the coast at 13 LT while we see a progressive increase in precipitation over the valley. In addition, a peak of convergence in the south of the basin occurs in the afternoon (Figure 7d; 16 LT) associated with the local daily peak of precipitation (Figure $6 \mathrm{~d}$; 16 LT). It is argued that this region corresponds to the zone of convergence between the regional southwestward flow and the local upward along-valley circulation. Besides, this local moisture flux would favor the precipitation in the basin highlands when the humidity transported reaches the slopes and the summit. Therefore, in the next section, we will focus on the times from 13 LT to 19 LT to better understand the local valley circulation and its influence over the precipitation.

\subsection{Regional and Local Atmospheric Processes Controlling the Afternoon and Early Night Precipitation}

The atmospheric processes between 13 LT and 19 LT are displayed in terms of wind mean and specific humidity anomalies at $700 \mathrm{hPa}$ and $850 \mathrm{hPa}$ in Figure 8, and in terms of wind mean at $10 \mathrm{~m}$ and specific humidity anomalies at $2 \mathrm{~m}$ in Figure 9. In particular, Figures 8 and 9 show the evolution of the wind and moisture flux from the outlet of the Santa River basin and how humidity is transported from the coast towards the summits and along the valley toward the south of the basin. At 13 LT, there are the strongest coastal upward winds at $850 \mathrm{hPa}$ (Figure $8 \mathrm{~d}$ ), with humidity being transported from lower levels toward the Cordillera Negra summits (Figure 9a). This is coherent with the maximum precipitation at 13 LT in the Cordillera Negra summits (Figure 6d). The coastal wind field shows interesting patterns at the outlet of Santa between 13 LT and 19 LT. The along-valley wind is the main feature at each time point considered, but with a maximum at 16 LT (Figure 8b). At this time, the regional Pacific winds turn strongly northeastward and perpendicular to the coast at $700 \mathrm{hPa}$, favoring a strong upward wind along the Santa valley (Figure 8b). At the same time, the regional Pacific southeastern winds, parallel to the coast, are still weak at $850 \mathrm{hPa}$, allowing local upward winds on the western slope of the Cordillera Negra, and strengthening the local Pacific wind in the transport of humidity upstream of the basin (Figure 8e). At $19 \mathrm{LT}$, the regional Pacific winds turn weakly northeastward at $700 \mathrm{hPa}$, while the regional Pacific southeasterly winds intensify alongshore at $850 \mathrm{hPa}$. In other words, this analysis suggests the crucial role of the intense regional Pacific northeastward wind at $700 \mathrm{hPa}$ and weak southeasterly winds at $850 \mathrm{hPa}$ over the local circulation in the Santa River basin between 13 LT and 16 LT, with a clear effect of the orographic channeling mechanism. It is remarkable that this channeling flow is not only the consequence of the Bernoulli effect, but it is also clearly intensified by the regional circulation. The diurnal cycle of the surface wind suggests, in addition, the influence of local mechanisms (Figure 9). As a result of the stronger sea-land temperature differences, at $13 \mathrm{LT}$, a westerly coastal flow (sea breeze), which probably intensifies due to the upslope thermally driven circulation, acts over the western side of the Cordillera Negra (including the outlet of the basin) with the consequent intensification of local upslope winds and moisture transport towards the Andes summits. This flow also reaches the basin, which contributes to moisture transport into the Santa Valley and intensifies the regional winds. Meanwhile, despite the surface upward flow disappearing at the outlet of the basin at 19 LT (Figure 9c), the along-valley moisture flow still exists upstream in the valley, but it is clearly weakened (Figure 9c). The diurnal cycle of the specific humidity anomalies shows coherent patterns with the diurnal cycle of the channeling flow. At 13 LT, a dipole anomaly of humidity is displayed with positive values at the outlet of the basin and negative values upstream in the valley south of $9^{\circ} \mathrm{S}$ and north of $8^{\circ} 30^{\prime} \mathrm{S}$ (Figures $8 \mathrm{a}$ and 9a). At $19 \mathrm{LT}$, this dipole is totally reversed, with strong negative anomalies of humidity at the outlet of the basin and positive ones upstream of the river (Figure 8c) and in the bottom of the valley below $3500 \mathrm{~m}$ (Figure 9c). Similar processes are found in the Marañon valley, with the strongest southwestward winds from the Marañón and the Amazon basin toward the Cordillera Blanca at 13 LT and 16 LT (Figure 8a,b) and the strongest humidity anomalies in the valley at 19 LT (Figure 8c). 


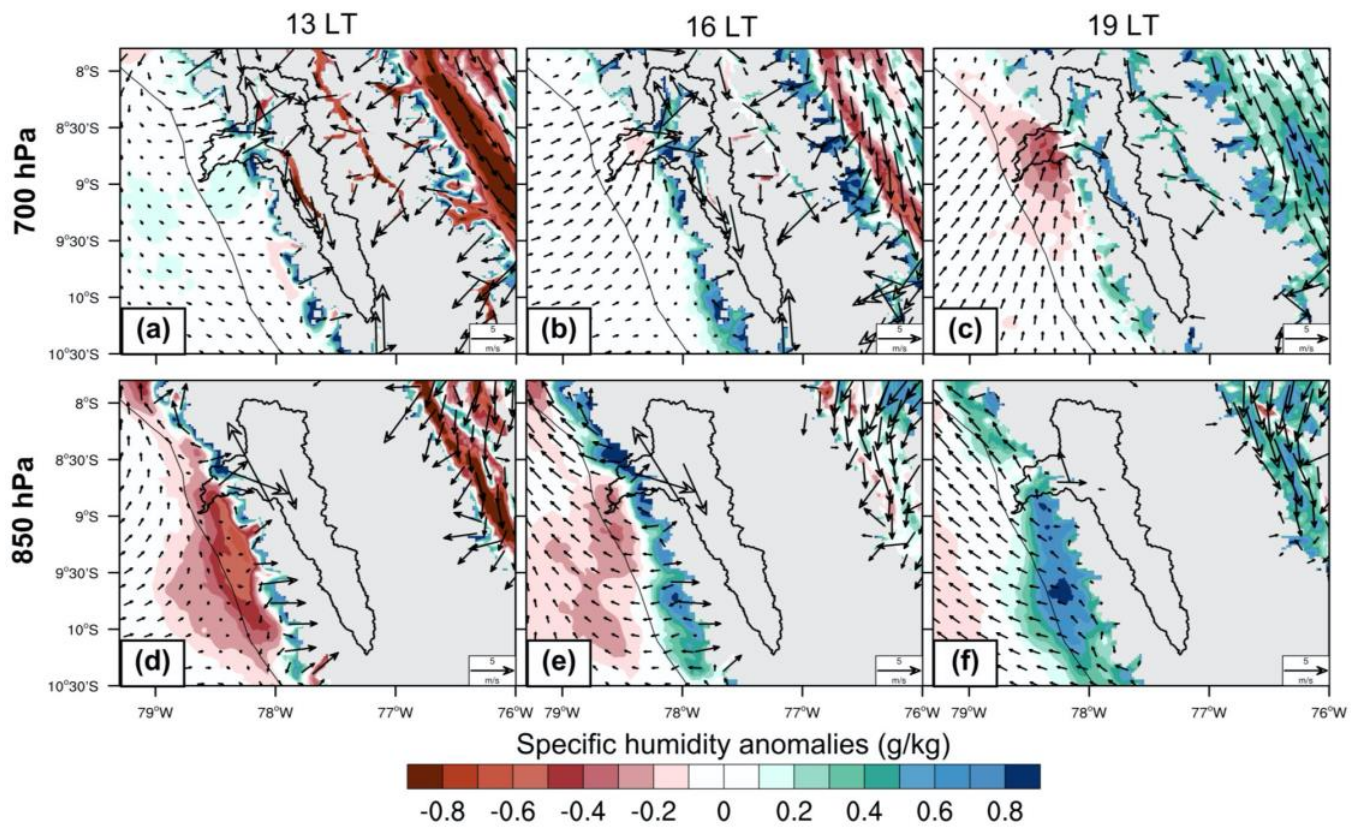

Figure 8. Horizontal wind (arrows, $\mathrm{m} \mathrm{s}^{-1}$ ) and anomaly of specific humidity (color shaded, $\mathrm{g} \mathrm{kg}^{-1}$ ) for DJFM as simulated by WRF-2 km for hourly means according to each time-step title minus daily mean (0-23 LT) at (a-c) $700 \mathrm{hPa}$ and (d-f) $850 \mathrm{hPa}$. The black lines delimitate Santa River basin and coastline.

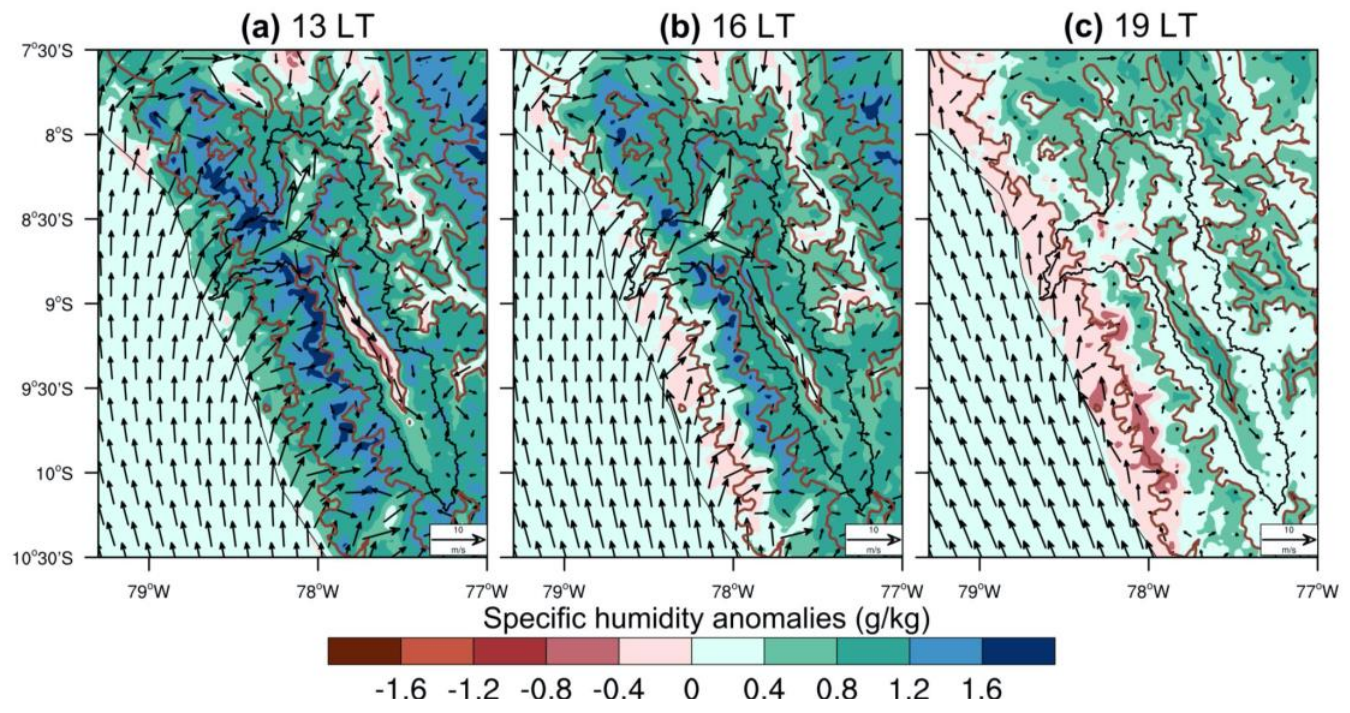

Figure 9. DJFM means of horizontal wind at $10 \mathrm{~m}$ (arrows, $\mathrm{m} \mathrm{s}^{-1}$ ) at (a) $13 \mathrm{LT}$, (b) $16 \mathrm{LT}$, and (c) 19LT and anomalous specific humidity at $2 \mathrm{~m}$ (color shaded, $\mathrm{g} \mathrm{kg}^{-1}$ ) from WRF-2 km for hourly means according to each time-step title minus all time step means. The black lines delimitate the Santa River basin and coastline.

Southwest-northeast cross-sections perpendicular to the valley are displayed in Figure 10. These figures confirm a progressive increase in humidity in the valley between $13 \mathrm{LT}$ and 19 LT. In addition, a cross-valley wind is present in the Santa valley at each time point of the afternoon, oriented toward the Cordillera Blanca. At 13 LT (Figure 10a), a reversal of the wind occurs, with the high-level westward wind turning eastward at the level of the Cordillera Negra, through localized subsidence. At 16 LT and 19 LT, however, upward motion is dominant, and the upward wind is stronger on the Cordillera Blanca slope than on the Cordillera Negra slope (Figure 10b,c). At 19 LT, the triggering convection is maximum at the center of the basin in the bottom of the valley below $3500 \mathrm{~m}$, 
with the largest moisture quantity, a weaker channeling horizontal flow, and an upward dominant motion.

(a) $13 \mathrm{LT}$

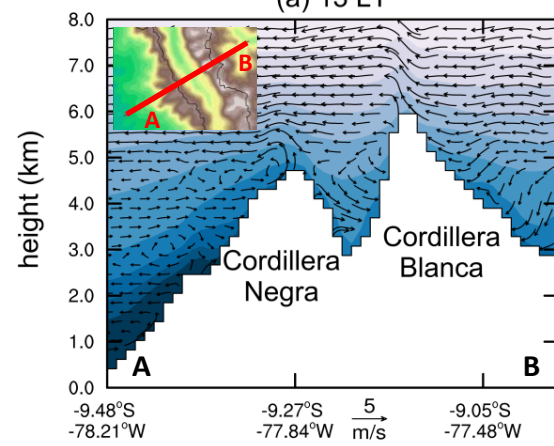

(b) $16 \mathrm{LT}$

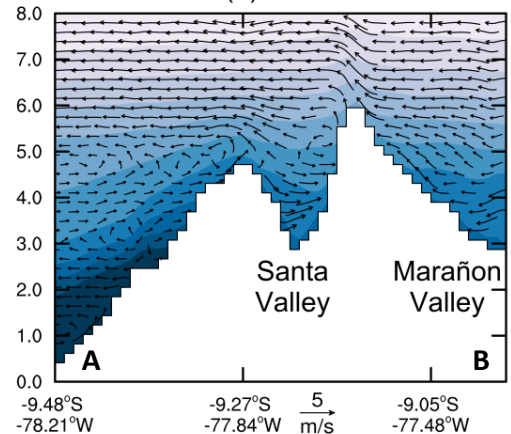

(c) $19 \mathrm{LT}$

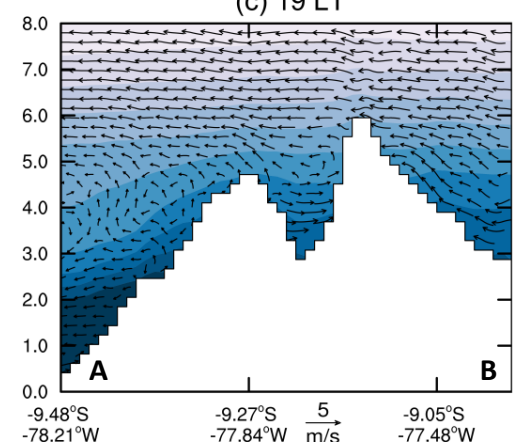

Specific humidity $(\mathrm{g} / \mathrm{kg})$

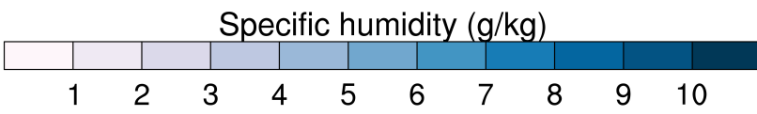

(d) $13 \mathrm{LT}$

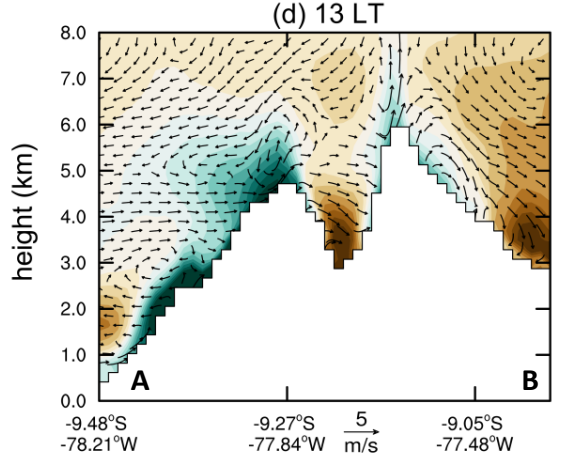

(e) $16 \mathrm{LT}$

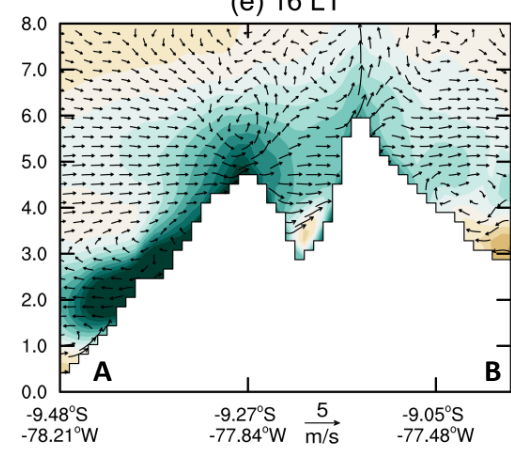

(f) $19 \mathrm{LT}$

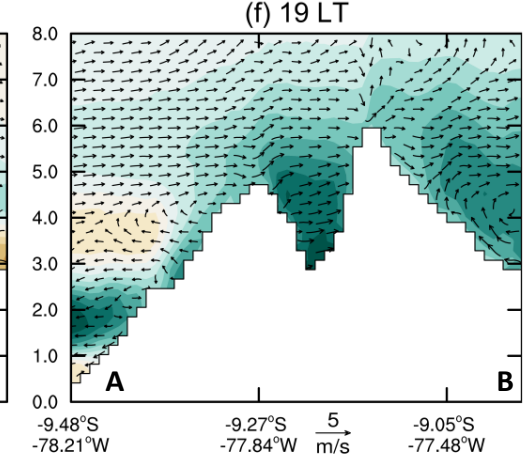

Specific humidity anomalies $(\mathrm{g} / \mathrm{kg})$

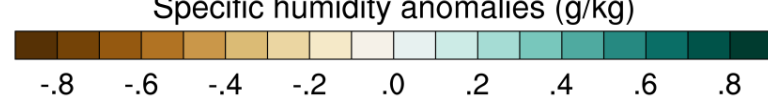

Figure 10. DJFM mean of the vertical cross-section of the meridional-vertical moisture flux (arrows, qv;qw) and specific humidity (colors; $\left.\mathrm{g} \mathrm{kg}^{-1}\right)(\mathbf{a}-\mathbf{c})$ means and $(\mathbf{d}-\mathbf{f})$ anomalies (each time-step title minus daily mean (0-23 LT)) from the WRF-2 km. The section is $\left(78.2^{\circ} \mathrm{W}, 9.49^{\circ} \mathrm{S}\right)-\left(77.33^{\circ} \mathrm{W}, 8.9^{\circ} \mathrm{S}\right)$. At the bottom, the reference vector is shown in $\mathrm{g} \mathrm{kg}^{-1} \mathrm{~m} \mathrm{~s}^{-1}$. The location of the cross-section and other geographical details are indicated in the inset panel (a).

These circulation patterns are in agreement with in situ stations measurements, showing convection triggered more or less early in the afternoon depending on the wind exposition, elevation, and north-south position in the basin. Following our results, two categories can be described: (i) The stations located in the extreme south and north of the basin with elevations above 3500 m present maximum precipitation around 16-17 LT; this time corresponds to the maximum conditions of the channeling flow intensified by the convection of the local upslope cross-valley winds and the regional northeasterlies from the Amazon basin (ex. Chiquian, Pasto Ruri; Figure 2); (ii) the stations located in the bottom of the valley below $3500 \mathrm{~m}$ show convection triggered later in the afternoon/early night, around 18-19 LT, corresponding to the decrease in the channeling flow and great moisture values, allowing the development of deep local convection (ex. Cañasbamba, Tingua; Figure 2). Obviously, most stations show a mix of these two diurnal cycles, certainly being influenced by both processes, and the simulation is not always able to perfectly reproduce the relative influence of each pattern. For example, the station of Quillcayhuanca, located at $3850 \mathrm{~m}$, shows precipitation beginning around 15 LT, corresponding to elevated conditions, and the simulation indicates an earlier triggering of the convection (Figure 2). However, the times of the day with the strongest convection are around 17-19 LT, corresponding to the local development of convection intensifying the earlier mechanism, which is aptly 
reproduced by WRF-2 $\mathrm{km}$. In general, the simulation tends to trigger convection earlier than the observations, suggesting that the simulated early afternoon upward wind might be overestimated. A more detailed representation of the topography with a higher horizontal resolution seems to partly resolve this shift (from $6 \mathrm{~km}$ to $2 \mathrm{~km}$, Figure 2).

\section{Summary and Conclusions}

The Santa River basin in Perú covers the largest concentration of tropical glaciers in the world and constitutes an important center of agriculture activities and electrical energy production.

High-spatial-resolution $(2 \mathrm{~km}$ ) simulations with the Weather Research and Forecasting model (WRF) were performed and analyzed to understand the interaction between local and regional atmospheric processes controlling precipitation over the Santa River basin in the Central Andes of Peru. For the rainy season of December of 2012 to March of 2013, one-way nested simulations were performed with two domains at $6 \mathrm{~km}$ (WRF-6 km) and $2 \mathrm{~km}$ (WRF-2 km) horizontal resolutions, forced by ERA5. Statistical analysis showed a clear improvement of WRF-2 km in contrast to WRF-6 km to simulate the daily mean and diurnal cycle of precipitation in greater agreement with in situ observations, even if both simulations overestimate the precipitation over the region. WRF-2 km simulates the spatial patterns of precipitation similar to the observed ones with better statistical performances than WRF-6 km and satellite datasets. WRF-2 km improves the diurnal cycle of precipitation by decreasing the time delay in triggering convection. Therefore, the finer resolution used in the nesting procedure improves the representation of local- and regional-scale processes associated with the formation of precipitation over all the elevated parts of Andes.

The main processes of interaction between regional and local circulation were described. Three hours in the afternoon (13 LT, 16 LT, and 19 LT) predominate for the triggered processes associated with the precipitation over the Santa River basin, as synthetized by the circulation scheme in Figure 11. It shows that the main precipitation patterns over the summits in the Cordilleras Negra and Blanca are strongly controlled by the entrance of regional winds alongshore. Therefore, the afternoon precipitation along the Santa valley is triggered by a channeling flow between 13 LT and 16 LT. The channeling flow is reinforced by local surface upward winds and a regional southeasterly circulation from the Pacific Ocean, turning perpendicular to the coast and parallel to the valley outlet orientation during the afternoon. In addition, as confirmed by some in situ station data, in the highest parts of the Santa River basin and its southern and northern parts, the afternoon precipitation maximum (16 LT) predominates earlier than in the lowest parts and the bottom of the valley (19 LT), associated with the intensification of the channeling flow by upslope cross-valley winds during mid-afternoon and its decrease during late afternoon/early night.

The presence of the channeling flow in the Santa valley and its diurnal cycle is a clear example of the complex interaction between orography, regional, and local circulation characteristics in the Santa River basin. The morphology of the mountains in the Santa valley is clearly the base of the channeling flow and is therefore controlling the afternoon precipitation. The circulation associated with the formation of precipitation over the Cordilleras Negra and Blanca is different. In the Cordillera Negra (nearer to the Pacific coast), precipitation is mainly controlled by the westerly coastal and upslope flow during the daytime. This flow enters the western side of the Cordillera Negra perpendicularly, producing convergence and moisture transport toward its upper parts during the early afternoon. In the Cordillera Blanca (nearer to the Amazon basin), the summit convergence of the upslope Santa valley winds (intensified by the upward along-valley flow) on its western side with the upslope winds on the eastern side (intensified by the upper-level easterly Amazon flow) explains the development of precipitation in the midafternoon. The configuration of the valley through an afternoon eastward cross-valley circulation between the Cordillera Negra and the Cordillera Blanca intensifies this upward flow and the moisture transport toward the summits of the Cordillera Blanca. Recently, [70] described 
differences in long-term seasonal variability of the water availability between the two cordilleras, which could be linked to the different local-regional atmospheric interactions described here.
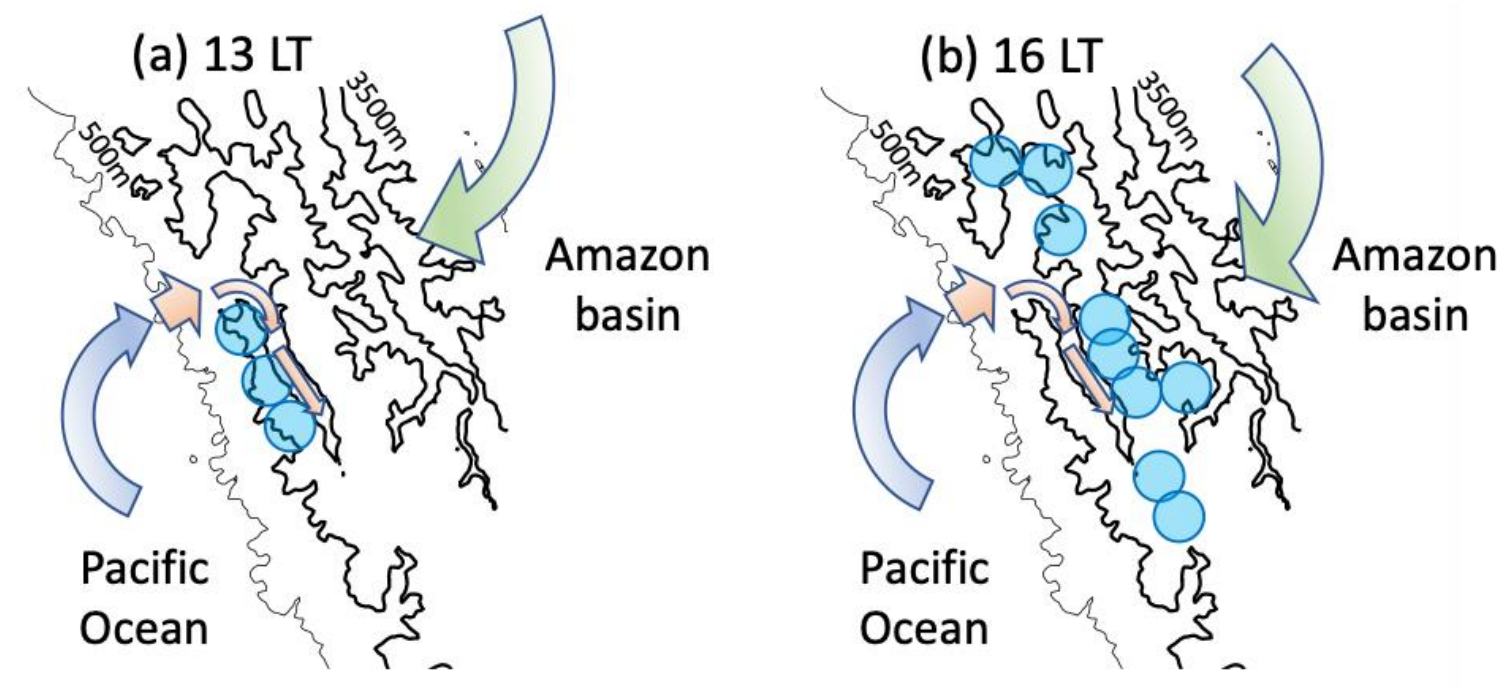

High precipitation

Vertical-integrated moisture Amazonian flow

Vertical-integrated moisture Coastal flow Channeling flow

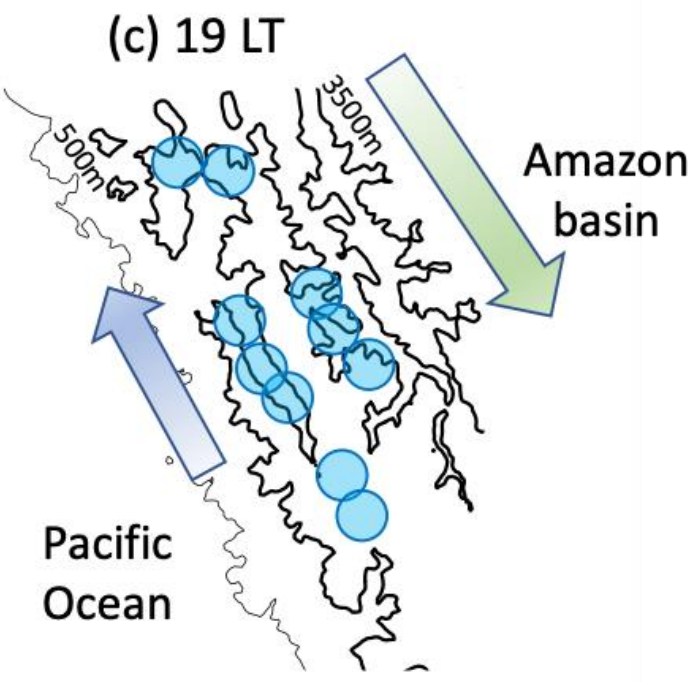

Figure 11. Schematic diagrams of the main atmospheric circulations in the region of the Santa River basin associated with the maximum precipitation according to model simulations for (a) 13 LT, (b) 16 LT, and (c) 19 LT DJFM means. The thin and bold black contours are topography limits at $500 \mathrm{~m}$ and $3500 \mathrm{~m}$, respectively.

In this study, the description of the atmospheric processes is limited by the fact that it depends on a unique WRF configuration. It is not known yet how these processes would change under different parameterization options or different forcing data and how it could affect the afternoon precipitation over the Santa River basin. For instance, previous papers have described the important role of the land-use data forcing over the spatial patterns of precipitation in the tropical Andes (e.g., [12,71]). In addition, [63] suggested that using different Cumulus or Microphysics schemes can affect the intensity of local patterns of surface circulation, for instance, the upward along-valley flow. Our validation indicates that simulations have the ability to represent regional (circulation was compared with ERA5) and local features (diurnal cycle of precipitation was compared with local stations) of the climate, giving the confidence to discuss processes in the Santa River basin. This does not eliminate those other options of parameterization that should be tested and analyzed in terms of atmospheric processes in the Santa River basin. 
The Pacific Ocean stands out as a source of moisture for the Cordillera Blanca and the Santa River basin precipitation through the establishment of channeling flow. Therefore, the moisture from the Pacific Ocean is a key process modulating the diurnal cycle of precipitation over the Santa River basin, in interaction with moisture fluxes from the Amazon basin. Further observational studies should be performed to confirm and quantify the relative importance of both oceanic and continental sources of moisture for the Santa River basin, including interannual variability, such as ENSO regimes. Indeed, [72] has described the influences of El Niño Southern Oscillation (ENSO) events over the glaciers' mass balance variability of the cordillera Blanca. Therefore, it would be interesting for future studies to investigate how ENSO events affect the local and regional atmospheric processes of the Santa River basin and the associated diurnal cycle precipitation patterns. Indeed, sea surface temperature (SST) anomalies off the coast of Peru have strong influences over the low-level circulation of Pacific Ocean circulation and, in particular, the Peruvian coastal wind (e.g., $[27,73,74])$. A more in-depth investigation would be needed in order to determine whether these anomalies could in turn influence the channeling flow mechanism at the outlet of the Santa River basin.

Supplementary Materials: The following are available online at https:/ /www.mdpi.com/article/10 .3390/atmos13020344/s1, Table S1: List of in situ rainfall stations from UNASAM and SENAMHI. * Indicates stations with the same positions for both.

Author Contributions: Formal analysis, A.G.R.; Supervision, C.J.; Validation, R.P.d.R.; Writingoriginal draft, A.G.R.; Writing — review \& editing, C.J., R.P.d.R., T.C. and J.-C.E. All authors have read and agreed to the published version of the manuscript.

Funding: The research publication was financed by the AMANECER-MOPGA project (ANR and IRD). Ref. ANR-18-MPGA-0008.

Data Availability Statement: All dataset sources except in situ data and WRF modeling results have been properly referenced by showing the source (website links). The datasets generated during the current study (WRF outputs) are available from the corresponding author on reasonable request.

Acknowledgments: The authors acknowledge Coordenação de Aperfeiçoamento de Pessoal de Nível Superior (CAPES) Finance Code 001, Conselho Nacional de Desenvolvimento Científico e Tecnológico (CNPq Grants \#430314/2018-3, \#304949/2018-3). J.C.E and C.J. have been partially supported by the French AMANECER-MOPGA project funded by ANR and IRD (ref. ANR-18-MPGA-0008). We thank Sly Wongchuig for helping with the citation format.

Conflicts of Interest: The authors declare no conflict of interest.

\section{References}

1. Zapata, M.; Arnaud, Y.; Gallaire, R. Inventario de Glaciares de La Cordillera Blanca. In Proceedings of the 13th IWRA World Water Congress, Montpellier, France, 1-4 September 2008.

2. Vignon, F. Glaciares y Recursos Hídricos en el Valle Alto del Río Santa. Ph.D. Thesis, Paris Diderot University, Paris, France, 2002.

3. Kaser, G.; Ames, A.; Zamora, M. Glacier Fluctuations and Climate in the Cordillera Blanca, Peru. Ann. Glaciol. 1990, 14, 136-140. [CrossRef]

4. Georges, C. 20th-Century Glacier Fluctuations in the Tropical Cordillera Blanca, Peru. Arct. Antarct. Alp. Res. 2004, 36, 100-107. [CrossRef]

5. Vuille, M.; Kaser, G.; Juen, I. Glacier Mass Balance Variability in the Cordillera Blanca, Peru and Its Relationship with Climate and the Large-Scale Circulation. Glob. Planet. Chang. 2008, 62, 14-28. [CrossRef]

6. Condom, T.; Escobar, M.; Purkey, D.; Pouget, J.C.; Suárez, W.; Ramos, C.; Apaestegui, J.; Tacsi, A.; Gómez, J. Simulating the Implications of Glaciers' Retreat for Water Management: A Case Study in the Rio Santa Basin, Peru. Water Int. 2012, 37, 442-459. [CrossRef]

7. Junquas, C.; Takahashi, K.; Condom, T.; Espinoza, J.-C.; Chavez, S.; Sicart, J.-E.; Lebel, T. Understanding the Influence of Orography on the Precipitation Diurnal Cycle and the Associated Atmospheric Processes in the Central Andes. Clim. Dyn. 2018, 50, 3995-4017. [CrossRef]

8. Mejía, F.; Douglas, M. Flow around the Andean Elbow from WRF Simulations and P-3 Aircraft Measurements during the SALLJEX. In Proceedings of the 8th International Conference on Southern Hemisphere Meteorology and Oceanography (ICSHMO), Foz de Iguaçu, Brazil, 24-28 April 2006; INPE: São José dos Campos, Brazil, 2006; pp. 795-802. 
9. Moya-Álvarez, A.S.; Martínez-Castro, D.; Flores, J.L.; Silva, Y. Sensitivity Study on the Influence of Parameterization Schemes in WRF_ARW Model on Short- and Medium-Range Precipitation Forecasts in the Central Andes of Peru. Adv. Meteorol. 2018, 2018, 1381092. [CrossRef]

10. Ochoa-Sánchez, A.E.; Pineda Ordonez, L.E.; Crespo, P.; Willems, P. Evaluation of TRMM 3B42 Precipitation Estimates and WRF Retrospective Precipitation Simulation over the Pacific-Andean Region of Ecuador and Peru. Hydrol. Earth Syst. Sci. 2014, 18, 3179-3193. [CrossRef]

11. Spiga, A.; Teitelbaum, H.; Zeitlin, V. Identification of the Sources of Inertia-Gravity Waves in the Andes Cordillera Region. Ann. Geophys. 2008, 26, 2551-2568. [CrossRef]

12. Saavedra, M.; Junquas, C.; Espinoza, J.-C.; Silva, Y. Impacts of Topography and Land Use Changes on the Air Surface Temperature and Precipitation over the Central Peruvian Andes. Atmos. Res. 2020, 234, 104711. [CrossRef]

13. Mourre, L.; Condom, T.; Junquas, C.; Lebel, T.; Sicart, J.E.; Figueroa, R.; Cochachin, A. Spatio-Temporal Assessment of WRF, TRMM and in Situ Precipitation Data in a Tropical Mountain Environment (Cordillera Blanca, Peru). Hydrol. Earth Syst. Sci. 2016, 20, 125-141. [CrossRef]

14. Skamarock, W.C.; Klemp, J.B.; Dudhia, J.; Gill, D.O.; Barker, D.M.; Duda, M.G.; Huang, X.-Y.; Wang, W.; Powers, J.G. A Description of the Advanced Research WRF Version 3; Technical Report NCAR/TN-475+STR; NCAR: Boulder, CO, USA, 2008; 125p.

15. Garreaud, R.D. The Andes Climate and Weather. Adv. Geosci. 2009, 22, 3-11. [CrossRef]

16. Houze, R.A. Orographic Effects on Precipitating Clouds. Rev. Geophys. 2012, 50, RG1001. [CrossRef]

17. Garreaud, R.D. Multiscale Analysis of the Summertime Precipitation over the Central Andes. Mon. Weather Rev. 1999, 127, 901-921. [CrossRef]

18. Espinoza, J.C.; Garreaud, R.; Poveda, G.; Arias, P.A.; Molina-Carpio, J.; Masiokas, M.; Viale, M.; Scaff, L. Hydroclimate of the Andes Part I: Main Climatic Features. Front. Earth Sci. 2020, 8, 64. [CrossRef]

19. Chavez, S.P.; Takahashi, K. Orographic Rainfall Hot Spots in the Andes-Amazon Transition According to the TRMM Precipitation Radar and In Situ Data. J. Geophys. Res. Atmos. 2017, 122, 5870-5882. [CrossRef]

20. Espinoza, J.C.; Chavez, S.; Ronchail, J.; Junquas, C.; Takahashi, K.; Lavado, W. Rainfall Hotspots over the Southern Tropical Andes: Spatial Distribution, Rainfall Intensity, and Relations with Large-Scale Atmospheric Circulation. Water Resour. Res. 2015, 51, 3459-3475. [CrossRef]

21. Garreaud, R.; Vuille, M.; Clement, A.C. The Climate of the Altiplano: Observed Current Conditions and Mechanisms of Past Changes. Palaeogeogr. Palaeoclimatol. Palaeoecol. 2003, 194, 5-22. [CrossRef]

22. Staal, A.; Tuinenburg, O.A.; Bosmans, J.H.C.; Holmgren, M.; van Nes, E.H.; Scheffer, M.; Zemp, D.C.; Dekker, S.C. Forest-Rainfall Cascades Buffer against Drought across the Amazon. Nat. Clim. Chang. 2018, 8, 539-543. [CrossRef]

23. Ampuero, A.; Stríkis, N.M.; Apaéstegui, J.; Vuille, M.; Novello, V.F.; Espinoza, J.C.; Cruz, F.W.; Vonhof, H.; Mayta, V.C.; Martins, V.T.S.; et al. The Forest Effects on the Isotopic Composition of Rainfall in the Northwestern Amazon Basin. J. Geophys. Res. Atmos. 2020, 125, e2019JD031445. [CrossRef]

24. Falvey, M.; Garreaud, R.D. Moisture Variability over the South American Altiplano during the South American Low Level Jet Experiment (SALLJEX) Observing Season. J. Geophys. Res. 2005, 110, D22105. [CrossRef]

25. Romatschke, U.; Houze, R.A. Extreme Summer Convection in South America. J. Clim. 2010, 23, 3761-3791. [CrossRef]

26. Enfield, D.B. Thermally Driven Wind Variability in the Planetary Boundary Layer above Lima, Peru. J. Geophys. Res. 1981, 86, 2005-2016. [CrossRef]

27. Takahashi, K. Thermotidal and Land-Heating Forcing of the Diurnal Cycle of Oceanic Surface Winds in the Eastern Tropical Pacific. Geophys. Res. Lett. 2012, 39, L04805. [CrossRef]

28. Trachte, K.; Seidel, J.; Figueroa, R.; Otto, M.; Bendix, J. Cross-Scale Precipitation Variability in a Semiarid Catchment Area on the Western Slopes of the Central Andes. J. Appl. Meteorol. Climatol. 2018, 57, 675-694. [CrossRef]

29. Gutman, G.J.; Schwerdtfeger, W. The Role of Latent and Sensible Heat for the Development of a High Pressure System over the Subtropical Andes, in the Summer (Role of Latent Heat in Development of Anticyclone Pressure System over Subtropical Andes during Summer Months_TIROS II Radiation Data); Springer: Berlin/Heidelberg, Germany, 1965; pp. 95-124.

30. Virji, H. A Preliminary Study of Summertime Tropospheric Circulation Patterns over South America Estimated from Cloud Winds. Mon. Weather Rev. 1981, 109, 599-610. [CrossRef]

31. Vera, C.; Higgins, W.; Amador, J.; Ambrizzi, T.; Garreaud, R.; Gochis, D.; Gutzler, D.; Lettenmaier, D.; Marengo, J.; Mechoso, C.R.; et al. Toward a Unified View of the American Monsoon Systems. J. Clim. 2006, 19, 4977-5000. [CrossRef]

32. Lenters, J.D.; Cook, K.H. Summertime Precipitation Variability over South America: Role of the Large-Scale Circulation. Mon. Weather Rev. 1999, 127, 409-431. [CrossRef]

33. Figueroa, S.N.; Satyamurty, P.; Da Silva Dias, P.L. Simulations of the Summer Circulation over the South American Region with an Eta Coordinate Model. J. Atmos. Sci. 1995, 52, 1573-1584. [CrossRef]

34. Aceituno, P.; Montecinos, A. Circulation Anomalies Associated with Dry and Wet Periods in the South American Altiplano. In Proceedings of the Fourth International Conference on Southern Hemisphere Meteorology, Hobart, Australia, 29 March-2 April 1993; pp. 330-331.

35. Kodama, Y. Large-Scale Common Features of Subtropical Precipitation Zones (the Baiu Frontal Zone, the SPCZ, and the SACZ) Part I: Characteristics of Subtropical Frontal Zones. J. Meteorol. Soc. Jpn. Ser. II 1992, 70, 813-836. [CrossRef] 
36. Marengo, J.A.; Liebmann, B.; Grimm, A.M.; Misra, V.; da Silva Dias, P.L.; Cavalcanti, I.F.A.; Carvalho, L.M.V.; Berbery, E.H.; Ambrizzi, T.; Vera, C.S.; et al. Recent Developments on the South American Monsoon System. Int. J. Climatol. 2012, $32,1-21$. [CrossRef]

37. Zhou, J.; Lau, K.M. Does a Monsoon Climate Exist over South America? J. Clim. 1998, 11, 1020-1040. [CrossRef]

38. Liebmann, B.; Marengo, J. Interannual Variability of the Rainy Season and Rainfall in the Brazilian Amazon Basin. J. Clim. 2001, 14, 4308-4318. [CrossRef]

39. Marengo, J.A.; Douglas, M.W.; Dias, P.L.S. The South American Low-level Jet East of the Andes during the 1999 LBA-TRMM and LBA-WET AMC Campaign. J. Geophys. Res. Atmos. 2002, 107, LBA-47. [CrossRef]

40. Segura, H.; Espinoza, J.C.; Junquas, C.; Lebel, T.; Vuille, M.; Garreaud, R. Recent Changes in the Precipitation-Driving Processes over the Southern Tropical Andes/Western Amazon. Clim. Dyn. 2020, 54, 2613-2631. [CrossRef]

41. Rodwell, M.J.; Hoskins, B.J. Subtropical Anticyclones and Summer Monsoons. J. Clim. 2001, 14, 3192-3211. [CrossRef]

42. Junquas, C.; Li, L.; Vera, C.S.; Le Treut, H.; Takahashi, K. Influence of South America Orography on Summertime Precipitation in Southeastern South America. Clim. Dyn. 2016, 46, 3941-3963. [CrossRef]

43. Poveda, G.; Mesa, O.J.; Salazar, L.F.; Arias, P.A.; Moreno, H.A.; Vieira, S.C.; Agudelo, P.A.; Toro, V.G.; Alvarez, J.F. The Diurnal Cycle of Precipitation in the Tropical Andes of Colombia. Mon. Weather Rev. 2005, 133, 228-240. [CrossRef]

44. Ruiz-Hernández, J.C.; Condom, T.; Espinoza, J.C.; Junquas, C.; Ribstein, P.; Villacis, M.; Lemoine, N.; Sicart, J.E.; Rabatel, A.; Campozano, L.; et al. Spatial Variability of Diurnal to Seasonal Cycles of Precipitation from a High-Altitude Equatorial Andean Valley to the Amazon Basin. J. Hydrol. Reg. Stud. 2021, 38, 100924. [CrossRef]

45. Campozano, L.; Célleri, R.; Trachte, K.; Bendix, J.; Samaniego, E. Rainfall and Cloud Dynamics in the Andes: A Southern Ecuador Case Study. Adv. Meteorol. 2016, 2016, 3192765. [CrossRef]

46. Egger, J.; Blacutt, L.; Ghezzi, F.; Heinrich, R.; Kolb, P.; Lämmlein, S.; Leeb, M.; Mayer, S.; Palenque, E.; Reuder, J.; et al. Diurnal Circulation of the Bolivian Altiplano. Part I: Observations. Mon. Weather Rev. 2005, 133, 911-924. [CrossRef]

47. Giovannettone, J.P.; Barros, A.P. Probing Regional Orographic Controls of Precipitation and Cloudiness in the Central Andes Using Satellite Data. J. Hydrometeorol. 2009, 10, 167-182. [CrossRef]

48. Reuder, J.; Egger, J. Diurnal Circulation of the South American Altiplano: Observations in a Valley and at a Pass. Tellus A Dyn. Meteorol. Oceanogr. 2006, 58, 254-262. [CrossRef]

49. Trachte, K.; Rollenbeck, R.; Bendix, J. Nocturnal Convective Cloud Formation under Clear-Sky Conditions at the Eastern Andes of South Ecuador. J. Geophys. Res. 2010, 115, 24203. [CrossRef]

50. Trachte, K.; Nauss, T.; Bendix, J. The Impact of Different Terrain Configurations on the Formation and Dynamics of Katabatic Flows: Idealised Case Studies. Bound.-Layer Meteorol. 2010, 134, 307-325. [CrossRef]

51. Funk, C.; Peterson, P.; Landsfeld, M.; Pedreros, D.; Verdin, J.; Shukla, S.; Husak, G.; Rowland, J.; Harrison, L.; Hoell, A.; et al. The Climate Hazards Infrared Precipitation with Stations-A New Environmental Record for Monitoring Extremes. Sci. Data 2015, 2, 150066. [CrossRef] [PubMed]

52. Huffman, G.J.; Adler, R.F.; Bolvin, D.T.; Gu, G.; Nelkin, E.J.; Bowman, K.P.; Hong, Y.; Stocker, E.F.; Wolff, D.B. The TRMM Multisatellite Precipitation Analysis (TMPA): Quasi-Global, Multiyear, Combined-Sensor Precipitation Estimates at Fine Scales. J. Hydrometeorol. 2007, 8, 38-55. [CrossRef]

53. Kummerow, C.; Simpson, J.; Thiele, O.; Barnes, W.; Chang, A.T.C.; Stocker, E. The Status of the Tropical Rainfall Measuring Mission (TRMM) after Two Years in Orbit. J. Appl. Meteorol. 2000, 39, 1965-1982. [CrossRef]

54. Joyce, R.J.; Janowiak, J.E.; Arkin, P.A.; Xie, P. CMORPH: A Method That Produces Global Precipitation Estimates from Passive Microwave and Infrared Data at High Spatial and Temporal Resolution. J. Hydrometeorol. 2004, 5, 487-503. [CrossRef]

55. Rosales, A.J.G. Valley-Mountain Circulation Associated with Precipitation Formation in the Tropical Andes (Rio Santa Basin). Master's Thesis, Universidade de São Paulo, São Paulo, Brazil, 2019.

56. Betts, A.K. A New Convective Adjustment Scheme. Part I: Observational and Theoretical Basis. Q. J. R. Meteorol. Soc. 1986, 112, 677-691. [CrossRef]

57. Betts, A.K.; Miller, M.J. A New Convective Adjustment Scheme. Part II: Single Column Tests Using GATE Wave, BOMEX, ATEX and Arctic Air-Mass Data Sets. Q. J. R. Meteorol. Soc. 1986, 112, 693-709. [CrossRef]

58. Janjić, Z.I. The Step-Mountain Eta Coordinate Model: Further Developments of the Convection, Viscous Sublayer, and Turbulence Closure Schemes. Mon. Weather Rev. 1994, 122, 927-945. [CrossRef]

59. Tao, W.-K.; Simpson, J.; McCumber, M. An Ice-Water Saturation Adjustment. Mon. Weather Rev. 1989, 117, 231-235. [CrossRef]

60. Nakanishi, M.; Niino, H. An Improved Mellor-Yamada Level-3 Model: Its Numerical Stability and Application to a Regional Prediction of Advection Fog. Bound.-Layer Meteorol. 2006, 119, 397-407. [CrossRef]

61. Niu, G.-Y.; Yang, Z.-L.; Mitchell, K.E.; Chen, F.; Ek, M.B.; Barlage, M.; Kumar, A.; Manning, K.; Niyogi, D.; Rosero, E.; et al. The Community Noah Land Surface Model with Multiparameterization Options (Noah-MP): 1. Model Description and Evaluation with Local-Scale Measurements. J. Geophys. Res. Atmos. 2011, 116, D12109. [CrossRef]

62. Yang, Z.; Niu, G.; Mitchell, K.E.; Chen, F.; Ek, M.B.; Barlage, M.; Longuevergne, L.; Manning, K.; Niyogi, D.; Tewari, M.; et al. The Community Noah Land Surface Model with Multiparameterization Options (Noah-MP): 2. Evaluation over Global River Basins. J. Geophys. Res. Atmos. 2011, 116, D12110. [CrossRef] 
63. Junquas, C.; Heredia, M.B.; Condom, T.; Ruiz-Hernández, J.C.; Campozano, L.; Dudhia, J.; Espinoza, J.C.; Menegoz, M.; Rabatel, A.; Sicart, J.E. Regional Climate Modeling of the Diurnal Cycle of Precipitation and Associated Atmospheric Circulation Patterns over an Andean Glacier Region (Antisana, Ecuador). Clim. Dyn. 2022. [CrossRef]

64. Nakanishi, M.; Niino, H. An improved Mellor-Yamada level-3 model with condensation physics: Its design and verification. Bound.-Layer Meteorol. 2004, 112, 1-31. [CrossRef]

65. Iacono, M.J.; Delamere, J.S.; Mlawer, E.J.; Shephard, M.W.; Clough, S.A.; Collins, W.D. Radiative Forcing by Long-Lived Greenhouse Gases: Calculations with the AER Radiative Transfer Models. J. Geophys. Res. Atmos. 2008, 113, D13103. [CrossRef]

66. Dudhia, J. Numerical Study of Convection Observed during the Winter Monsoon Experiment Using a Mesoscale Two-Dimensional Model. J. Atmos. Sci. 1988, 46, 3077-3107. [CrossRef]

67. Da Rocha, R.P.; Morales, C.A.; Cuadra, S.V.; Ambrizzi, T. Precipitation Diurnal Cycle and Summer Climatology Assessment over South America: An Evaluation of Regional Climate Model Version 3 Simulations. J. Geophys. Res. Atmos. 2009, 114, D10108. [CrossRef]

68. Condom, T.; Martínez, R.; Pabón, J.D.; Costa, F.; Pineda, L.; Nieto, J.J.; López, F.; Villacis, M. Climatological and Hydrological Observations for the South American Andes: In Situ Stations, Satellite, and Reanalysis Data Sets. Front. Earth Sci. 2020, 8, 92. [CrossRef]

69. Rasmussen, K.L.; Choi, S.L.; Zuluaga, M.D.; Houze, R.A. TRMM precipitation bias in extreme storms in South America. Geophys. Res. Lett. 2013, 40, 3457-3461. [CrossRef]

70. Hänchen, L.; Klein, C.; Maussion, F.; Gurgiser, W.; Calanca, P.; Wohlfahrt, G. Vegetation indices as proxies for spatio-temporal variations in water availability in the Rio Santa valley (Peruvian Andes). Earth Syst. Dyn. Discuss. 2021, 1-28. [CrossRef]

71. Sierra, J.P.; Junquas, C.; Espinoza, J.C.; Segura, H.; Condom, T.; Andrade, M.; Molina-Carpio, J.; Ticona, L.; Mardoñez, V.; Blacutt, L.; et al. Deforestation Impacts on Amazon-Andes Hydroclimatic Connectivity. Clim. Dyn. 2021. [CrossRef]

72. Maussion, F.; Gurgiser, W.; Großhauser, M.; Kaser, G.; Marzeion, B. ENSO Influence on Surface Energy and Mass Balance at Shallap Glacier, Cordillera Blanca, Peru. Cryosphere 2015, 9, 1663-1683. [CrossRef]

73. Chamorro, A.; Echevin, V.; Colas, F.; Oerder, V.; Tam, J.; Quispe-Ccalluari, C. Mechanisms of the Intensification of the UpwellingFavorable Winds during El Niño 1997-1998 in the Peruvian Upwelling System. Clim. Dyn. 2018, 51, 3717-3733. [CrossRef]

74. Oerder, V.; Colas, F.; Echevin, V.; Masson, S.; Hourdin, C.; Jullien, S.; Madec, G.; Lemarié, F. Mesoscale SST-Wind Stress Coupling in the Peru-Chile Current System: Which Mechanisms Drive Its Seasonal Variability? Clim. Dyn. 2016, 47, 2309-2330. [CrossRef] 